Discussion Paper No. 03-27

\title{
Three Approaches to the Evaluation of Active Labour Market Policy in East Germany Using Regional Data
}

Tobias Hagen

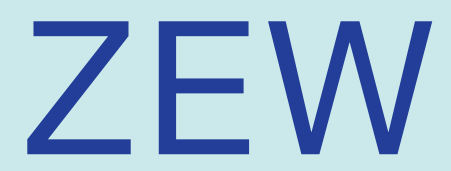

Zentrum für Europäische Wirtschaftsforschung GmbH

Centre for European Economic Research 
Discussion Paper No. 03-27

\title{
Three Approaches to the Evaluation of Active Labour Market Policy in East Germany Using Regional Data
}

\author{
Tobias Hagen
}

Download this ZEW Discussion Paper from our ftp server:

\author{
ftp://ftp.zew.de/pub/zew-docs/dp/dp0327.pdf
}

Die Discussion Papers dienen einer möglichst schnellen Verbreitung von neueren Forschungsarbeiten des ZEW. Die Beiträge liegen in alleiniger Verantwortung der Autoren und stellen nicht notwendigerweise die Meinung des ZEW dar.

Discussion Papers are intended to make results of ZEW research promptly available to other economists in order to encourage discussion and suggestions for revisions. The authors are solely responsible for the contents which do not necessarily represent the opinion of the ZEW. 


\section{Non Technical Summary}

Active labour market programmes haven been extensively used during the East German transformation process. Between 1990 and 2002 the Federal Employment Office ('Bundesanstalt für Arbeit') spent approximately 138 billion EURO for ALMP in East Germany. During this period of time 6.5 million workers participated in public sponsored training or job creation schemes, which corresponds approximately with the current number of employees. Since the mid-1990s there is some empirical evidence on the effects of East German active labour market policy (ALMP), especially job creation schemes $(J C S)$ and public training measures $(P T)$. Most of these studies are based on microeconomic approaches, i.e. they evaluate the direct effects for the participants in comparison to a control group of non-participants. Given that suitable data are available, the advantage of micro studies is the possibility of detailed estimation of heterogeneous effects for different sub-populations. The majority of available microeconometric evaluation studies indicate no positive or even negative effects of $P T$ and $J C S$ schemes on the future employment prospects of participants in comparison to a suitable control group.

However, a fundamental assumption in micro studies is that the non-participants are not affected by the evaluated programme. The more extensive a measure is, the higher is the probability of indirect employment effects on the non-participants. Therefore, microeconomic evaluation of ALMP can only estimate the gross effects of the measures for the participants. Since ALMPs are implemented to a large scale in East Germany, indirect effects are likely to be significant. Macroeconometric evaluation studies can take the indirect effects into account and may estimate the net effects of ALMP.

Aggregate evaluation studies are associated with a fundamental methodical problem. ALMP cannot be treated as exogenous with respect to the local labour market condition. This has to be taken into account in order to obtain an unbiased estimate of the local effect of ALMP.

In this paper the three largest ALMP programmes - job creation schemes (JCS), structural adjustment schemes $(S A S)$, and public sponsored training $(P T)-$ are evaluated.

The analysis of the regional allocation rule of the funding of ALMPs reveals that ALMP cannot be treated as exogenous: The allocation depends on the regional labour market situation, i.e. those regions with the worst situation obtain the most funding. This makes the use of suitable econometric approaches dealing with this simultaneity problem essential

Three different approaches are presented in this paper: (1) an augmented matching function which evaluates the effects of ALMPs on regional matching efficiency (inflows into regular employment), (2) a reduced-form approach based on the Beveridge curve, which assesses the effects on the regional job seeker rate (the unemployment rate plus the participants in ALMP), and (3) a regional labour demand. Two different regional data sets for the period of 1997 until 2002 are used.

The augmented matching function indicates negative effects of $J C S$ on matching efficiency (inflows into regular employment) and no significant effects of $P T$ and $S A S$. 
This result is in line with available microeconometric research. The augmented Beveridge curve approach does not indicate any long-term effects of ALMPs on regional job-seeker rates. The labour demand estimation indicates that $P T$ has no effects on employment and $J C S$ even leads to crowding-out of regular employment. 


\title{
Three Approaches to the Evaluation of Active Labour Market Policy in East Germany Using Regional Data*
}

\author{
Tobias Hagen
}

\begin{abstract}
Using different regional data sources for East Germany the three largest active labour market policy (ALMP) programmes - job creation schemes $(J C S)$, structural adjustment schemes $(S A S)$ and public training $(P T)$ - are evaluated. After addressing the regional allocation rule of the funding of ALMPs and the fundamental simultaneity problem in macroeconomic evaluation studies, identification strategies and possible instrumental variables are discussed. Three different approaches based on different econometric techniques for panel data (GMM and two-stage least squares) are applied. An augmented matching function indicates a negative effect of $J C S$ on regional matching efficiency (inflows into regular employment) and no significant effects of $P T$ and $S A S$. A reduced form approach based on the Beveridge curve does not indicate any long-term effects of ALMPs on regional job seeker rates. A dynamic labour demand estimation indicates that $P T$ has no effects on employment and JCS leads to displacement of regular employment.
\end{abstract}

Keywords: Evaluation, Active Labour Market Policy, Identification, Regional Data, Matching Efficiency, Crowding-out

JEL Classification: C33, E24, H43, J68

Contact: Phone: +49 / 621 / 1235 -288, Fax: +49 / 621 / 1235 -225, e-mail: hagen@zew.de

*Acknowledgement: The author wishes to thank Thiess Büttner, Bernd Fitzenberger and Karsten Kohn for their valuable comments. Furthermore the author is grateful to Uwe Blien and Annette Haas for enabling the access to some regional data. Dirk Engel gave me essential advice on the use of district level data. I thank Susanne Steffes for her excellent assistance. 
Active labour market policy has been extensively implemented during the East German transformation process. Between 1990 and 20026.5 million workers participated in public training or job creation schemes. Since the mid-1990s there is some empirical evidence on the effects of East German active labour market policy (ALMP), especially job creation schemes and public training measures. Most of these studies are based on microeconomic approaches, i.e. they evaluate the direct effects for the participants in comparison to a control group of non-participants (average treatment effect of the treated). ${ }^{1}$ If suitable data are available, micro studies can reveal detailed heterogeneous effects for different sub-populations. ${ }^{2}$

A fundamental assumption in micro studies is the stable unit treatment value assumption (RUBIN, 1980): the labour market situation of the control group consisting of non-participants is not affected by the evaluated programme. The more extensive a measure is, the higher is the probability of indirect employment effects on the nonparticipants. Therefore microeconomic evaluation of ALMP can only estimate the gross effects of the measures for the participants and the results may be biased by the violation of the mentioned assumption (see HECKMAN et al., 1999). Since in East Germany large-scale ALMP programmes are implemented, indirect effects are likely to be significant. Macroeconometric evaluation studies can take the indirect effects into account and may estimate the net effect of ALMP. ${ }^{3}$ In this paper the three largest active labour market policy programmes - job creation schemes (JCS), structural adjustment schemes $(S A S)$, and public training measures $(P T)$ - are evaluated. JCS and $S A S$ are subsidised jobs, mostly implemented in the non-profit sector.

The majority of available mircoeconometric evaluation studies indicate no positive or even negative effects of $P T$ and $J C S$ schemes on the future employment prospects of participants in comparison to a suitable control group (see HUJER and CALIENDO, 2001; HAGEN and STEINER, 2000). In a new study using large administrative data sets HUJER et al. (2003) cannot detect any positive employment effects for any subpopulation of participants in JCS.

The fundamental evaluation problem in macroeconometric evaluation studies is that ALMP is likely to be an endogenous variable. Local labour market offices may raise their expenditures on ALMP if the labour market situation becomes worse. Therefore, methods dealing with this simultaneity problem have to be applied in order to identify the effect of ALMPs.

The effects found in previous studies using regional data are mixed. ${ }^{4}$ Some of the results are, however, likely to be affected by the methodological problems mentioned

Surveys for German studies are for example HUJER and CALIENDO (2001) as well as HAGEN and STEINER (2000). The current state of the macroeconomic literature is also presented in FERTIG et al. (2002). Surveys on international experiences on ALMPs can be found in MARTIN (2000), HECKMAN et al. (1999), FAY (1996) and STEINER and HAGEN (2002).

2 See for example LECHNER (2001) as well as HECKMAN et al. (1997).

3 Other approaches which are suitable to take into account indirect effects are general equilibrium models (see HECKMAN et al., 1999).

4 See BütTNER and Prey (1998); STEINER et al. (1998); SCHMID et al. (2001); HAGEN and STEINER (2000), BLIEN et al. (2002) and FERTIG et al. (2002). For surveyes see the references cited in footnote 1. 
above. One should keep in mind that macroeconometric evaluation is in comparison to microeconometric evaluation still in its infancy from a methodological point of view. ${ }^{5}$ Therefore this paper tries to make also a methodological contribution to this topic.

Three different approaches are presented in this paper: (1) an augmented matching function which evaluates the effects of ALMPs on regional matching efficiency, (2) a reduced-form approach based on the Beveridge curve which assesses the effects on the regional job seeker rate (the unemployment rate plus the participants in ALMP) and (3) a regional labour demand. The econometric analysis is performed with two-stage least square estimators based on first-differenced variables as well as GMM dynamic panel data estimators.

The paper is structured as follows: After a brief description of the institutional background in the next section, effects of ALMP are discussed and possible empirical strategies for their analysis are derived in section 3. Section 4 describes the regional data sets used. Section 5 includes an analysis of the regional allocation rule of funding for ALMPs, the detailed specifications, the estimation techniques, and the results of the three approaches. Finally, section 6 discusses the results and draws conclusions.

\section{Institutional Background: Active Labour Market Programmes in East Germany}

Between 1990 and 2002 the Federal Employment Office ('Bundesanstalt für Arbeit') spent approximately 138 billion EURO for ALMP in East Germany. ${ }^{6}$ During this period of time 6.5 million workers participated in public training measures or job creation schemes. This corresponds approximately with the number of employees at the present (see Bundesanstalt für Arbeit, 2003). This enormous amount of ALMP has been seen as necessary in order to support the transformation process and to avoid undue social hardship resulting from the high and increasing unemployment in East Germany. The most important measures have been public training ('geförderte berufliche Weiterbildung', $P T$ ) and subsidised employment, consisting of job creation schemes ('Arbeitsbeschaffungsmaßnahmen', JCS) and structural adjustment schemes ('Strukturanpassungsmaßnahmen', SAS) (see Table 1).

An extensive survey on the Swedish experiences can be found in CALMFORS et al. (2001). Sweden is an interesting example since it has traditionally implemented large-scale ALMP programmes.

5 "The problem of indirect effects poses a major challenge to conventional micro methods used in evaluation research that focus on direct impacts instead of total impacts, and demonstrates the need for program evaluation to utilize market-wide data and general equilibrium methods." (HECKMAN et al., 1999: 2035).

6 The unification of the former German Democratic Republic (East Germany) and the Federal Democratic Republic (West Germany) took place in October 1990. 
Table 1: Unemployment Rates and ALMP, 1991 - 2001 (percentages)

\begin{tabular}{l|rrrrrrrrrrr}
\hline \hline & 1991 & 1992 & 1993 & 1994 & 1995 & 1996 & 1997 & 1998 & 1999 & 2000 & 2001 \\
\hline Unemployment Rate West & 6.3 & 6.6 & 8.2 & 9.2 & 9.3 & 10.1 & 11.0 & 10.5 & 9.9 & 8.7 & 8.3 \\
Unemployment Rate East & 10.3 & 14.8 & 15.8 & 16.0 & 14.9 & 16.9 & 19.5 & 19.5 & 19.0 & 18.8 & 18.9 \\
Registered Vacancies East & 0.4 & 0.4 & 0.5 & 0.7 & 0.8 & 0.8 & 0.8 & 1.1 & 1.0 & 0.9 & 0.9 \\
JCS East & 2.1 & 4.9 & 3.2 & 2.7 & 2.9 & 2.7 & 2.2 & 2.2 & 2.4 & 2.0 & 1.6 \\
SAS East & & & 0.3 & 1.2 & 1.5 & 1.2 & 1.1 & 2.3 & 2.5 & 1.4 & 0.9 \\
$P T$ East & 3.2 & 6.2 & 5.2 & 3.6 & 3.6 & 3.3 & 2.6 & 2.1 & 2.0 & 1.9 & 1.9 \\
\hline \hline
\end{tabular}

Notes: Annual averages. JCS, SAS, PT are stocks of corresponding participants divided by total labour force.

Source: Federal Employment Office.

The objective of $P T$ is to increase the employability of the unemployed and the employment stability of employees at risk of becoming unemployed by enhancing the human capital of the participants. The costs of the training measures are paid by the employment office. Furthermore participants receive an assistance which depends on the previous net income and is approximately equal to the unemployment benefit (see the remarks of the German unemployment compensation below).

$J C S$ are subsidised jobs mostly in non-profit organisations. One principle of JCS is that their projects should be 'additional', i.e. not performed by regular firms. The aim of this regulation is to minimise displacement effects. JCS are temporary employment relationships especially for former long-term unemployed. The duration is normally 12 months, but can be prolonged to 36 months in special cases. The wage subsidy paid to the employing institution is between 30 and 100 per cent. The wages paid to the participants are equal to the wages according to collective agreements in corresponding jobs. Since, however, the relevance of collective wage agreements has decreased in East Germany, the remuneration in JCS is likely to be often higher than in regular jobs.

The second important wage subsidy scheme is $S A S$. The main difference to JCS is that it is more often carried out by the private sector and that employees at risk of becoming unemployed can participate as well. The subsidy is up to the average amount of unemployment benefit including social security contributions paid in Germany. The duration is normally up to 36 months. It can be extended to 48 months if the employer guarantees to offer the participants a regular job afterwards.

Participants in all ALMP programmes are not registered as unemployed and therefore reduce the rate of open unemployment. Furthermore, participants in JCS and SAS are registered as employed covered by the social security. Participating in JCS and $S A S$ qualifies for the eligibility of unemployment benefit.

The effective duration of the measures is on average much shorter than the potential duration reported above. In 1999 JCS lasted on average 8.3 months. The average duration of $P T$ and $S A S$ was 8.4 months and 9.8 months, respectively (see HUJER et al. 2002).

The German system of unemployment compensation consists of two parts, unemployment benefit ('Arbeitslosengeld', henceforth $U B$ ) and unemployment assistance ('Arbeitslosenhilfe', henceforth $U A$ ). Unemployed persons receive $U B$ if they were employed at least for 12 months within the previous three years. The amount of the 
monthly $U B$ is $60 \%$ (67\% for people with children) of the previous net wage. The entitlement period depends on the age and the previous employment duration and goes up to 32 months for older workers. If an unemployed person is not entitled to $U B$ or if the $U B$ is exhausted, $U A$ is available. The requirement is 5 months of employment during the previous 4 years. $U A$ amount to $53 \%$ ( $57 \%$ for people with children) of previous the net wage, whereas, in principle, it can be drawn indefinitely. UA payments are, however, under certain circumstances reduced by other incomes of the unemployed person as well as earnings of family members within limits.

\section{Possible Effects of Active Labour Market Policy and Empirical Strategies}

Besides potential effects of ALMPs at the level of participants in comparison to the hypothetical situation of non-participation (approximated by a suitable control group), effects at the macroeconomic level have to be taken into account. ${ }^{7}$

An extensive theoretical framework for the effects of ALMP has been developed by CALMFORS (1994) (see also CALMFORS and SKEDINGER, 1995 and CALMFORS et al., 2001). The effects can be summarised as follows (see also HuJER et al. 2002): (1) effects on the matching process, (2) effects on the productivity of participants, (3) effects on wage-formation and (4) effects on labour supply. ${ }^{8}$ Furthermore there may occur negative indirect effects on non-participants.

In the terminology of CALMFORS (1994) the following negative indirect effects may arise. Substitution effects occur if jobs created for subsidised workers (participants) replace regular workers because relative wage costs or productivity have changed. If substitution effects prevail, ALMP does not increase the scale but change the composition of outflow from unemployment. Therefore, substitution effects redistribute employment opportunities without increasing the level of employment. ${ }^{9}$ Note that substitution effects may occur also in the public sector where especially municipal authorities have an incentive to substitute regular employment by subsidised workers ('fiscal substitution effect'). Displacement effects occur if jobs created by a programme are at the expense of other jobs, e.g. by distortions on good markets. For example, goods produced by subsidised public employment may lead to distortion of competition and may therefore displace regular employment. ${ }^{10}$ It is called a deadweight effect, if an employer hires a subsidised worker, whom he had also hired in the absence of the measure. Since the expenditures for ALMP have to be financed, there are also tax effects. Taxes, or more important for the German case, social security contributions, ${ }^{11}$ can influence e.g. the labour-supply, labour-demand, or wage-setting behaviour. Since

\footnotetext{
7 Note that macroeconomic level means here the local labour market as well as the aggregate nation-wide labour market.

Another effect mentioned by CALMFORS et al. (2001) is on the allocation of the work force between sectors.

9 Note that the redistribution of employment prospects may be an objective for policy makers (see the discussion in JOHNSON and TOMOLA, 1977).

For example, there has been a great deal of debate about whether JCS in horticulture and landscaping (Garten- und Landschaftsbau) lead to crowding out of private firms in East Germany.

In Germany labour market policy is mainly financed by social security contributions.
} 
there is no regional variation in social security contributions and only a relatively small time dimension, tax effects cannot be identified in the following empirical analyses.

Labour-supply may be increased by ALMP, since discouragement-effects due to unemployment are probably mitigated. Furthermore, programmes may encourage people being out-of-labour force and especially women to re-enter the labour market by participating for example in training measures. Furthermore, the fact that participating in $J C S$ and $S A S$ qualifies for $U B$ keeps the unemployed in contact with the labour office after the participation. A positive labour supply effect within a region may be caused by reduced regional mobility due to ALMP, which may be particularly important for East Germany. ${ }^{12}$ However, by normalising all dependent variables in the following empirical analyses by the size of the labour force, labour-supply effects are not addressed.

The productivity of (former) participants may be increased by formal training $(P T)$ or learning-on-the job (JCS or $S A S)$. Thus, at the regional level average productivity of the work force may be increased which may lead under certain assumptions to an increase in labour demand (see CALMFORS et al. 2001). Of course, at given wages, also non-participants may be just substituted by (former) participants.

There are at least three potential channels how ALMP may affect wage-formation. First, if wage-formation depends on open unemployment, ALMP decreases the wagemoderating effect of high unemployment. Second, ALMP reduces the welfare differences between having and not having a job by paying participants higher incomes than unemployed non-participants, by improving the psychological well-being of participants in comparison to non-participation, by improving future labour market prospects, and by allowing participants to renew their eligibility for unemployment compensation. The reduced welfare difference may increase wage pressure at the individual level (efficiency wages) as well as at the collective level (bargaining models). Third, if the productivity of participants is increased and discouragement effects are mitigated, the relative reemployment probabilities of the outsiders (e.g. long-term unemployed participating in a measure) are increased which leads to a reduction of insider power and, therefore, a moderation of wage pressure. A potential approach to the evaluation of the wage-formation effects of ALMP is to estimate an augmented wage curve. This is for example applied in PANNENBERG and SCHWARZE (1996) who detect a wage moderating effect of $P T$ in East Germany. Here wage effects are not explicitly evaluated but they are, nevertheless, part of the net effects estimated.

Raising the efficiency of the matching process is usually regarded as the main aim of ALMP. At constant labour demand employment may be raised by an increase of matching efficiency. This can be reached by (1) increasing the search intensity of (former) participants, (2) by adjusting the human capital of job searchers to the requirement of labour demand, and (3) by improving the signals of job searchers. Microeconometric studies cast doubt particularly on an increased search intensity due to ALMPs. It has been frequently found, that participants get locked-in, i.e. they reduce

12

Since the unification in 1990 there has been significant migration from East to West Germany which is prevalently labour market driven. An often made statement is that ALMP may prevent laggard East German regions from "bleeding to death". 
their effort to find a regular job while they participate in the programme in comparison to the control group of non-participants (see for example BERGEMANN et al., 2000 as well as HUJER et al., 2003). This negative locking-in effect has to be overcompensated by positive employment effects due to the participation in the programme (see VAN OURS, 2002). In order to evaluate the effects of ALMPs on the matching efficiency, one can make use of the well-known matching function, which explains the number of matches (inflows into regular employment) with the number of job searchers and vacancies (see PETRONGOLO and PISSARIDES, 2001). Specifying a matching technology and augmenting the function by variables representing ALMPs, it is possible to evaluate the effect of ALMPs on the matching efficiency (see BOERI and BURDA, 1996 and BELLMANN and JACKMAN, 1996). The matching efficiency may be expressed as a shift-parameter of the Beveridge curve: An increase in the matching efficiency means an increase in inflows into regular employment, given the matching technology, the stock of the vacancies and the stock of job searchers. This approach is used in the analysis in section 5.2.

As mentioned above, ALMP may induce crowding-out of regular employment. The estimated effect of ALMPs within an augmented matching function already includes substitution effects which reflect the possibility that employers hire a (former) participant instead of a non-participant, but it does not include effects which are based on the possibility that regular workers are fired to be replaced by subsidised workers or that distortions at the good markets induce plant closures. In order to obtain these effects one can focus on stocks. A reduced form approach which includes all the effects may be interpreted as an augmented Beveridge curve as proposed by CALMFORS and SKEDINGER (1995) and HUJER et al. (2002). This approach - presented in section 5.3 regresses the regional job seeker rate (which is the unemployment rate plus participant rates in ALMPs) on the regional vacancy rate, structural variables describing the regional labour market, as well as variables for the ALMPs. Although the estimated effect of ALMP will include all indirect effects, the augmented Beveridge curve has the drawback to be a reduced form approach, which means that it is something of a "black box", i.e. it is unclear which of the effects discussed above drive the results.

A more structural approach for the assessment of crowding-out effects is to estimate a labour demand equation for regular labour. Most favourable would it be to estimate a heterogeneous labour demand with subsidised workers or former participants as one type of labour. This would enable the researcher to estimate substitution elasticities between different input factors and, therefore, to obtain a comprehensive pattern of the range of substitution and displacement effects. ${ }^{13}$ This is, however, due to data limitations not possible here. ${ }^{14}$ In section 5.4 a homogeneous regional labour demand for regular employment augmented by variables for ALMP is estimated.

\footnotetext{
13 To the best of my knowledge there is no study available yet, evaluating the effects of ALMP within a heterogeneous labour demand framework. firm level data. Using this approach HUJER, CALIENDO and RADIC (2002) cannot find any positive longrun effect of subsidised employment on firms' employment level for West Germany.
} 
There are two different data sources used in the econometric analyses: First, local employment office area (LEOA) ('Arbeitsamtsbezirke') data and, second, district ('Regierungskreise') data.

The LEOA data are available on a monthly basis from December 1998 up to January 2003. ${ }^{15}$ Due to data availability, Berlin (including the former West Berlin) is pooled into one district. It seems to be reasonable to treat Berlin as one regional labour market. This implies 35 regional units. These monthly data are used for the Beveridge curve approach presented in section 5.3.

The dependent variable in the Beveridge curve approach is the job seeker rate which is defined as the sum of the registered unemployed plus the participants in ALMPs (here JCS, PT, SAS and two smaller wage subsidy schemes ${ }^{16}$ ) relative to total labour force. In line with the literature the ALMP variables are defined as accomodation ratios, i.e. the participants in the measure of interest relative to the sum of the open unemployed and the participants in ALMP (see CALMFORS and SKEDINGER, 1995). Thus the accomodation ratios indicate the proportion of all unemployed who participate in the particular measure. Another variable used in the estimation is the number of shorttime workers. Some descriptive statistics of these variables for the estimation sample can be found in Table A1 in the Appendix. It can be seen that the JSR is much higher than the rate of open unemployment. In some local areas even one third of the total labour force are job searchers and one fifth of all job searchers are participants in JCS.

For the augmented matching function in section 5.2 the monthly LEOA data have to be pooled into quarterly data, since the dependent variable 'inflows into employment' is only available for quarters. The data covers the time period between the first quarter in 1999 and the first quarter in 2002. The dependent variable is corrected for the inflows into ALMPs (JCR and $S A S)$ in order to obtain inflows into 'regular employment'. All variables are normalised by local labour force. Some descriptive statistics of important variables in the estimation sample can be found in Table A2 in the Appendix. It can be seen that during a quarter there are 4.7 inflows into employment per 100 persons in the total labour force. 5.5 per cent of these inflows are into JCS or SAS. In order to obtain additional (instrumental) variables district data are merged to the LEOA data. In most cases direct matches are possible. Otherwise the data are merged weighted with weights depending on population size. By doing this information on political elections at the district level and welfare recipients can be used for the analyses.

For the labour demand estimation in section 5.4 district level data are used. ${ }^{17}$ This data set is available for the 114 East German districts for 1996 until 2000. Berlin has to be excluded since not all variables are available. Furthermore, due to administrative

\footnotetext{
15 These data can be downloaded from the homepage of the Federal Employment Office at www.arbeitsamt.de.

The schemes are called „Beschäftigungshilfen für Langzeitarbeitslose“ and „Eingliederungszuschüsse“. The district level data are obtained from three sources: (1) the 'Bundesministerium für Bauwesen und Raumordnung “Aktuelle Daten zur Entwicklung der Städte, Kreise und Gemeinden”” , (2) 'Bundesamt für Bauwesen und Raumordnung "INKAR - Indikatoren zur Raumentwicklung"' and (3) the Institute of Employment Research (IAB) at the Federal Employment Office.
} 
changes in the district structure, some districts have to be aggregated which leads to a reduction to 101 districts. ${ }^{18}$ Unfortunately, SAS is not available for 1996 . Therefore it is excluded from the analysis. In the econometric analyses employment and the measures of ALMP are normalised by total labour force. Some descriptive statistics can be found in Table A3 in the Appendix.

\section{$5 \quad$ Econometric Analysis}

As mentioned above, the results of three different approaches to the evaluation of ALMPs are presented in this section. First of all, in the next subsection, the crucial issue of the endogeneity of ALMP and possible instrumentation strategies are discussed.

\subsection{Endogeneity of Active Labour Market Policy and Potential Instrumental Variables}

The fundamental problem in macroeconomic evaluation studies is that ALMP cannot be treated as strictly exogenous since it may depend on the contemporaneous or lagged labour market situation. This would lead to a correlation of the ALMP variables with the error term and consequently to inconsistent estimates of the effects. The usual solution is to apply instrumental variable estimators. In the following, it is shown that, due to the allocation rule of the funding, ALMP has to be interpreted as endogenous with respect to the local labour market situation.

Generally, ALMP is implemented by local employment offices ('Arbeitsämter') even if the funding comes from the Federal Employment Office ('Bundesanstalt für Arbeit'). There is another level in between the local employment offices and the federal employment office, the so-called regional employment offices ('Landesarbeitsämter'). The regional employment offices correspond approximately to the federal states ('Bundesländer'), even though in some cases more than one federal state is assigned to a regional employment office.

The allocation of the funding of ALMPs on the local employment offices is predominantly based on regional and local labour market factors (see BLIEN, 2002; FERTIG and SCHMIDT, 2000). In the first step the total funding is determined by the Federal Employment Office ('Bundesanstalt für Arbeit') for one year. This is of course influenced by government decisions. The funding is divided into two approximately equal parts for East and West Germany, respectively. Afterwards, the allocation on regional employment offices depends on (1) the change in regional employment, (2) the regional job seeker rate, (3) the regional proportion of unemployed with low reemployment probabilities (long-term unemployed, older, disabled), and (4) the number of exits from unemployment into regular employment. Furthermore, in order to guarantee a certain "steadiness" of ALMP the current funding depends on the funding

18 The following towns that became administered as a district in its own right during the period had to be aggregated with their surrounding areas: Chemnitz, Plauen, Mittweida, Zwickau, Dresden, Meißen, Kamenz, Leipzig, Delitzsch. 
of the previous year. In the third step regional employment offices allocate the funding on local employment offices using similar local labour market indicators. Especially after the introduction of the new employment promotion in the Social Code (Sozialgesetzbuch III; SGB) in January 1998 the local employment offices have been to a large extent autonomous in their implementation of ALMPs (see FERTIG and SCHMIDT, 2000).

The presented allocation rule implies that ALMP is indeed endogenous with respect to the regional and local labour market situation which implies that treating ALMP as an exogenous variable in empirical analyses will yield inconsistent results.

The Relationship between the local job seeker rate and ALMP is depicted in Figure 1 and Figure 2. Based on non-parametric regressions (see HÄRDLE, 1991) and monthly LEOA data, it is shown that the proportion of participants in labour force increases with the $J S R$ (Figure 1). An increase in the JSR is associated with a stronger increase in JCS than in $P T$. This becomes more obvious when looking on the association between the JSR and accomodation ratios (proportion of job seeker participating in a certain measure) in Figure 2. Equivalent figures can also be shown for the relationships between ALMP and the other outcome measures (inflows into regular employment and level of regular employment). These are not depicted for lack of space.

Figure 1: Relationship between the job seeker rate and ALMP (participants relative to the labour force) - Results of nonparametric regressions

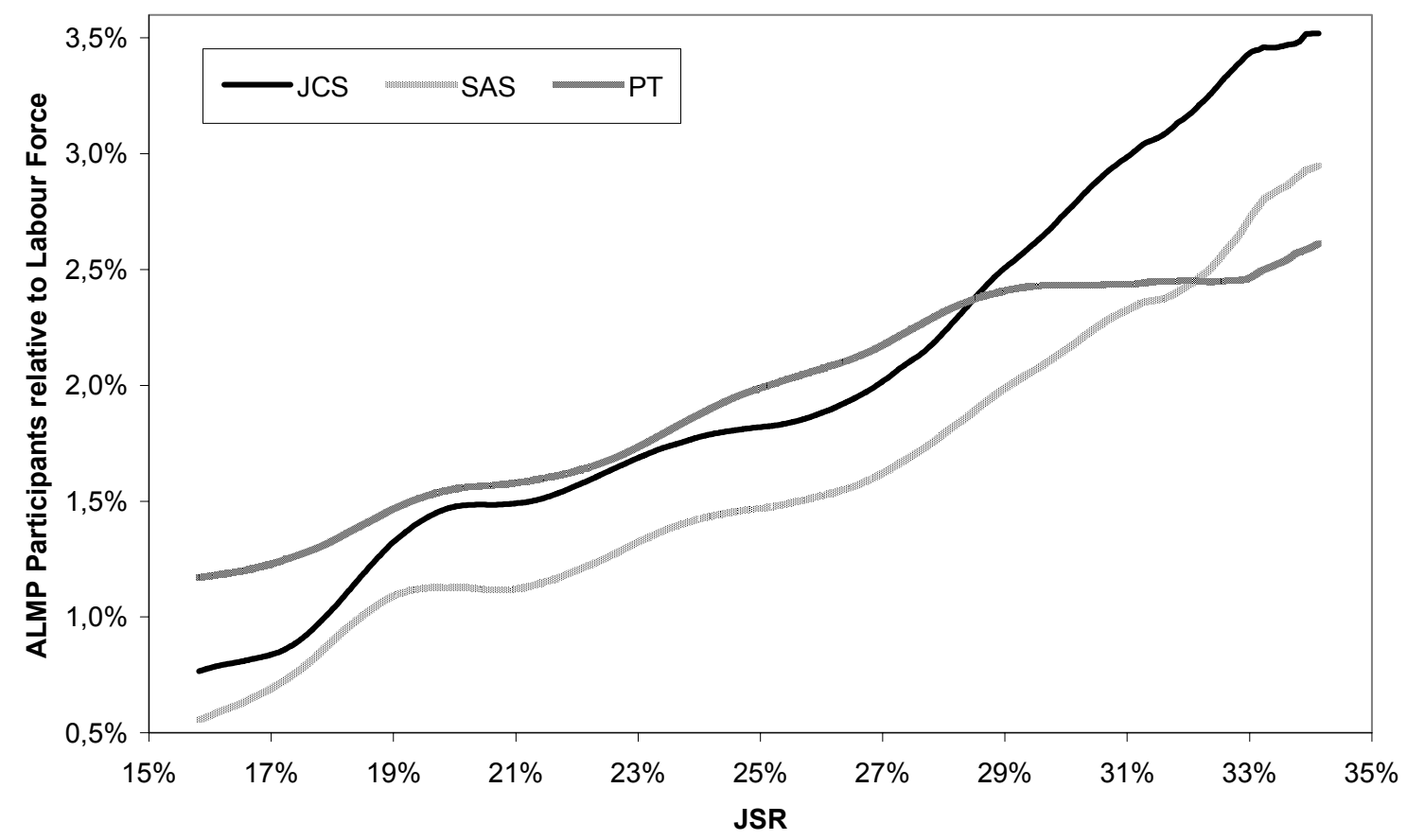

Notes: Bivariate Nadaraya-Watson estimator with an Epanechnikov kernel and a bandwidth of 0.02, based on 1,750 observations (35 LEOAs, Dec. 1998 - Jan. 2003). 
Figure 2: Relationship between the job seeker rate and ALMP (acccomodation ratios) - Results of nonparametric regressions

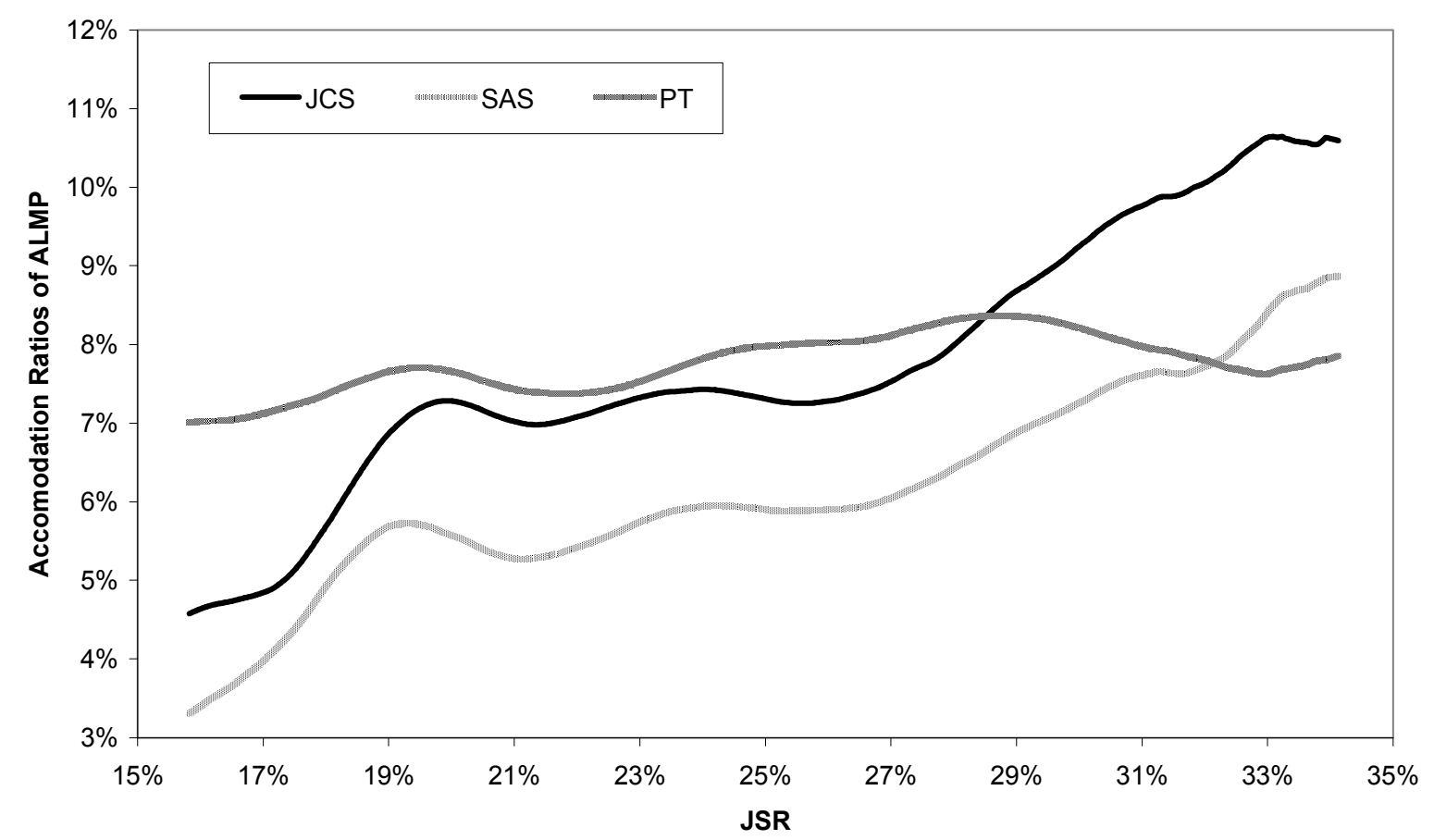

Notes: See Figure 1.

All the indicators of the allocation rule are obviously no suitable instrumental variables since they are correlated or even identical with the dependent variables in the econometric analysis. Potential instruments may be variables which influence the discretionary decisions of local authorities and employment offices (see BÜTTNER and PREY, 1998). Such instrumental variables which have been partly used in the literature are political factors, the proportion of welfare recipients, (at least in the short-run) the structure of the labour force and the national unemployment and vacancy rate.

It is often stated that parties on the political Left have a stronger preference for ALMP than liberal-conservative parties (see for example CALMFORS and SKEDINGER, 1995; BÜTTNER and PREY, 1998). Regional governments have the possibility to promote the implementation of measures through several channels (see PREY, 1999). Therefore, in this paper the proportion of votes for liberal-conservative parties (CDU and FDP) is used as an instrument. ${ }^{19}$

The proportion of welfare recipients may be correlated with ALMP (especially JCS and $S A S$ ) since local political authorities have an incentive to 'transform' welfare recipients which are funded by the local community into participants of labour market programmes and afterwards recipients of unemployment benefit (see FEIST and SCHÖB, 2000). ALMP as well as unemployment benefit is funded by the federal employment office. This incentive has also been described for Belgium (see COCKX and RIDDER, 2001).

19 CDU refers to the "Christlich Demokratische Union Deutschlands" and FDP to the "Freie Demokratische Partei Deutschlands". 
The national unemployment rate may be a valid instrument for two reasons. First, it is one central variable for the government which determines judgement by the voters. The government has the possibility to decrease the open unemployment rate in the short-run just by the fact that participants in ALMPs are not defined as unemployed. Thus it may raise it's funding for ALMP if open unemployment increases. ${ }^{20}$ Second, given the restricted budget of the federal employment office, an increase in unemployment may also lead to a reduction of ALMP spending in the region concerned if its increase in unemployment is lower. This tendency is strengthened by the fact that rising national unemployment rates lead to rising spending for passive labour market policies (unemployment benefit and assistance, short-term work etc.). The influence of a single East German region on national variables is negligible. Furthermore, the variable is lagged in order to avoid any simultaneity problems.

The national vacancy rate may serve as a business cycle indicator. A reduction in the national vacancy rate may again cause the government to increase ALMP spendings. The structure of the local labour force may influence the implementation of different ALMP measures on the local level since particular programmes are only suitable for special groups.

\subsection{Augmented Matching Function - Effects on Matching Efficiency}

The aggregate matching function assumes that the outflow from unemployment in employment (new matches) $H_{i t}$ in region $i$ and period $t$ is a function $m$ of the number of unemployed job searchers $U_{i t}$ and the number of vacancies $V_{i t}$

$$
H_{i t}=A_{i t} \cdot m\left(U_{i t}, V_{i t}\right) \quad m_{U}>0, \quad m_{V}>0
$$

with $A_{i t}$ representing a mismatch parameter which may vary over time and over regions (see PETRONGOLO and PISSARIDES, 2001 for a survey).

Assuming a Cobb-Douglas function for $m$, taking logarithm on both sides and taking some random variations in matching into account, (1) can be reformulated as a regression equation

$$
h_{i t}=\beta_{1} u_{i t}+\beta_{2} v_{i t}+\delta t+\gamma S+\eta_{i}+\varepsilon_{i t}
$$

with the lower case denoting the natural logarithm. Furthermore the variables are normalised by total labour force $h_{i t}=\ln \left(H_{i t} / L_{i t}\right){ }^{21}$ The mismatch parameter $A_{i t}$ is decomposed into $\ln \left(A_{i t}\right)=\delta t+\gamma S+\eta_{i}+\varepsilon_{i t}$, with $\eta_{i}$ denoting a regional fixed-effect on the

\footnotetext{
20 The political economy of active labour market policy is discussed in CALMFORS (1995). He formulates a game between government and wage-setters which leads to the problem of time-inconsistency which is well-known from the theory of monetary policy. Since the government cannot credibly announce low spending for ALMP wages are set above the market clearing level. If one assumes that a conservative party has a lower weight for open unemployment in its loss function, the commitment outcome can be obtained also under discretion.

As shown by MÜNICH, SVEJNAR and TERRELL (1998), not taking into account the size of the local units leads to biased estimation due to the intercorrelations among the variables, termed "spurious scale effect" by the authors.
} 
matching efficiency, $t$ is a deterministic time trend which accounts for changes in matching efficiency over time which is common to all regions, $S$ denotes a vector of seasonal (quarterly) dummies, and $\varepsilon_{i t}$ is a classical error term. From a theoretical point of view it is an interesting question whether the estimated parameters are conform with constant return to scale (see PISSARIDES, 2000). This can be tested by defining the null hypothesis as $\beta_{1}+\beta_{2}=1$.

In order to incorporate ALMPs into the matching function the implicit assumption of a homogeneous pool of job searchers is relaxed and search effectiveness is included into the matching function (see LEHMANN, 1995 and PUHANI, 1999). After rearranging (2), one gets the following equation (see also BOERI and BURDA, 1996 and BELLMANN and JACKMAN, 1996):

$$
h_{i t}=\beta_{1} u_{i t}+\beta_{2} v_{i t}+\beta_{3} Z_{i t}+\beta_{4} p_{i t}^{1}+\beta_{5} p_{i t}^{2}+\beta_{6} p_{i t}^{3}+\delta t+\gamma S+\eta_{i}+\varepsilon_{i t}
$$

with $Z_{i t}$ denoting variables affecting the search effectiveness of the job searchers (structure of the unemployed and the labour force) and $p_{i t}^{1}, p_{i t}^{2}, p_{i t}^{3}$ the (logarithm of the) stock of participants in three different ALMP programmes (JCS, SAS, PT) normalised by total labour force. Descriptive statistics can be found in Table A2 in the Appendix.

In practice, all explanatory variables are set to the begin of the period $t$, i.e. the end of period $t-1 .{ }^{22}$ The time lag of the effect of the ALMP is ex ante unknown. Since the average duration of the ALMPs analysed is between 8 and 10 months, the ALMPs variables are lagged up to 4 quarters.

$$
\begin{aligned}
h_{i t}= & \beta_{1} u_{i t-1}+\beta_{2} v_{i t-1}+\beta_{3} Z_{i t-1}+\sum_{k=1}^{4} \beta_{4 k} p_{i, t-k}^{1}+\sum_{k=1}^{4} \beta_{5 k} p_{i, t-k}^{2}+\sum_{k=1}^{4} \beta_{6 k} p_{i, t-k}^{3} \\
& +\delta t+\gamma S+\eta_{i}+\varepsilon_{i t}
\end{aligned}
$$

Running this regression on the data set used is associated with some problems, which are well-known in the empirical literature (see PETRONGOLO and PISSARIDES, 2001). First, the dependent variable $h_{i t}$ does include all inflows into regular employment and not only the inflows from unemployment. Although this definition of $h_{i t}$ is well-suited for the analysis here, ${ }^{23}$ equation (4) does not correspond to the traditional matching function. Second, the vacancy rate $v$ includes only the registered vacancies at the employment office and is therefore systematically underreported (see FRANZ and SMOLNY, 1994). Nevertheless, in the absence of better data the reported vacancies may serve as a proxy for the actual vacancies. Third, the registered unemployment rate $u_{i t}$ disposes of the well-known under- and over-reporting bias: people not seeking for jobs but being registered are counted as unemployed while the ones seeking for jobs but not being registered as unemployed are called not unemployed. Especially when interpreting the estimated $\beta_{1}$ and $\beta_{2}$ these issues should be kept in mind.

\footnotetext{
22 Otherwise all variables would be endogenous with respect to $h_{i t}$.

23 This ensures that inflows from programmes are included. Furthermore, the possibility of substitution effects with regular on-the-job searchers is taken into account.
} 
In order to eliminate the regional-specific effect $\eta_{i}$, equation (4) is estimated in first differences. First-differencing is superior to fixed-effects in this application since it allows to use lagged values of variables which are not strictly exogenous as instruments. This is not a valid solution in fixed-effects models since the fixed-effects transformation leads to correlation of the error term with the time-demeaned instruments (see WOOLDRIDGE, 2002: 310). ${ }^{24}$

An essential issue is to control for dynamics, i.e. to include lagged dependent variables $\left(h_{i t-1}\right)$ as regressors. Due to the small sample size $(N=35 ; T=8$ in the preferred specification) the usual GMM estimator by ARRELANO and BOND (1991) or BLUNDELL and BOND (1998) seems not to be feasible (see also the discussion in HUJER et al. 2002). Using the inefficient ANDERSON and HSIAO (1981) two stage least square first-difference estimator, the null hypothesis of the coefficient of the lagged dependent variable is equal to zero, cannot be rejected. ${ }^{25}$ Therefore, unlike the approaches presented in the next sub-sections there is no lagged dependent variable included in the following. This, however, may lead to two problems. The falsely omitted lagged dependent variable may induce omitted variable bias. Furthermore, it may induce serial correlation which violates the use of lagged values of variables as instruments. Therefore, tests on serial correlation are performed (see WOOLDRIDGE, 2002).

The endogeneity of the ALMP is taken into account by a two-stage least square procedure. The first step is estimated by a seemingly-unrelated regression (SUR), since the analysed programmes are likely to be determined by the same or correlated unobserved factors. Note that SUR estimation does not affect consistency, but efficiency of the estimate (see BALTAGI, 2001). Besides the instrumental variables all exogenous variables of equation (4) are included, except for lagged vacancies. The reason is that there may be - especially for $S A S$ - anticipatory effects of firms' behaviour with regard to the reporting of vacancies: It is reasonable that firms report their vacancies to the employment office with a higher probability if they want to hire a subsidised worker. Therefore the vacancy rate may be correlated with the error term in the first stage regression and is therefore omitted. ${ }^{26}$

The results of the first-stage regression are depicted in Table A4 in the Appendix. The included linear time trend may control for the overall funding for ALMP as determined by the Federal Employment Office. The funding especially for JCS and SAS has been cut since 1999, which may be an explanation for the negative coefficients. The interaction variable with the political votes may capture the differential effect of the overall funding in different districts due to local governments. Furthermore, an additional interaction term of the political power variable with proportion of welfare recipients and the time trend controls for different concepts of political parties in their labour market policy for welfare recipients. Note, that only those labour force variables are included which have been found to have no significant effects on inflows into

\footnotetext{
24 The mean-deviation transformation for fixed-effects models leads to $y_{i t}-\bar{y}_{i}=+\beta^{\prime}\left(x_{i t}-\bar{x}_{i}\right)+\left(\varepsilon_{i t}-\bar{\varepsilon}_{i}\right)$, with the bar indicating the mean over time for a region $i$. Consistency requires that $E\left\{\left(x_{i t}-\bar{x}_{i}\right) \varepsilon_{i t}\right\}=0$.

25 Estimation results are available on request by the author

26 Indeed, the vacancy rate has a significantly positive effect on $S A S$ but not on $P T$ and JCS. Using this instrumentation strategies does not change the estimated effects of ALMP in the second stage. These estimation results are available on request by the author.
} 
regular employment. As an additional safeguard all instrumental variables are lagged at least for one period.

The results of the matching function (second stage) are depicted in Table 2. Column (1) includes an ordinary matching function consisting of the unemployment and the vacancy rate as well as seasonal dummies and a linear time trend as explanatory variables. Constant returns to scale are clearly rejected. The evidence is more in favour for increasing returns to scale. The coefficient of the time trend indicates decreasing matching efficiency over time. In column (2) the unemployment rate is decomposed into the short- and long-term unemployment rate (less and more than six months of unemployment, respectively). The short-term unemployment rate has a significantly larger effect on the inflows into regular employment than the long-term unemployment rate. This is compatible with negative duration dependence in the hazard rate into employment, often discussed in microeconometric unemployment duration analysis (see MACHIN and MANNING, 1999). Negative duration dependence may, for example, be caused by the assumption of a ranking of the unemployed corresponding with their unemployment duration (see BLANCHARD and DIAMOND, 1994) or appreciation of human capital. It is, however, well-known that the estimated result may be driven by the structure of the unemployed and not by true duration dependence. Therefore, in column (3) variables are included which have been found in microeconomic studies of unemployment duration to have significant effects (see e.g. HUNT, 1995 and STEINER, 2001). ${ }^{27}$ The results indicate that the higher the proportion of UB recipients in the pool of unemployment the lower the inflows into regular employment. ${ }^{28}$ This is in line with basic job search theory and the results in most microeconomic studies on unemployment duration (see for example HUNT, 1995; STEINER, 1997; ATKINSON and MiCKLEWRIGT, 1991). In column (4) the (log) participants in ALMPs are included but treated as exogenous. Now, constant returns to scale cannot be rejected. Finally, in column (5) the ALMP variables are instrumented. ${ }^{29}$ The Hausman test indicates that OLS in column (4) is inconsistent. The Sargan test does not reject the validity of the instruments.

The estimated elasticities of the inflows into regular employment with respect to the ALMP measures are summarised in Table 3. Treating the ALMPs variables as exogenous yield no significant elasiticities. Instrumenting the ALMP variables leads to significant negative effects of JCS. The cumulated elasticity after four quarters indicates that an increase in the participants in JCS per labour force by one per cent leads to an decrease of inflows into regular employment by approximately 0.95 per cent. Thus $J C S$ lead to a decline in regional matching efficieny. This result is compatible with the negative results at the micro level (see HUJER et al., 2003). Additionally, there may be negative indirect effects on the non-participants at the local labour market level.

\footnotetext{
27 All other variables describing the structure of the unemployed and the labour force turned out to be insignificant.

28 Data on UA are unfortunately not available.

29 The standard errors are adjusted for the fact that the ALMP variables are instrumented.
} 
Table 2: Estimation Results-Aggregate Matching Function

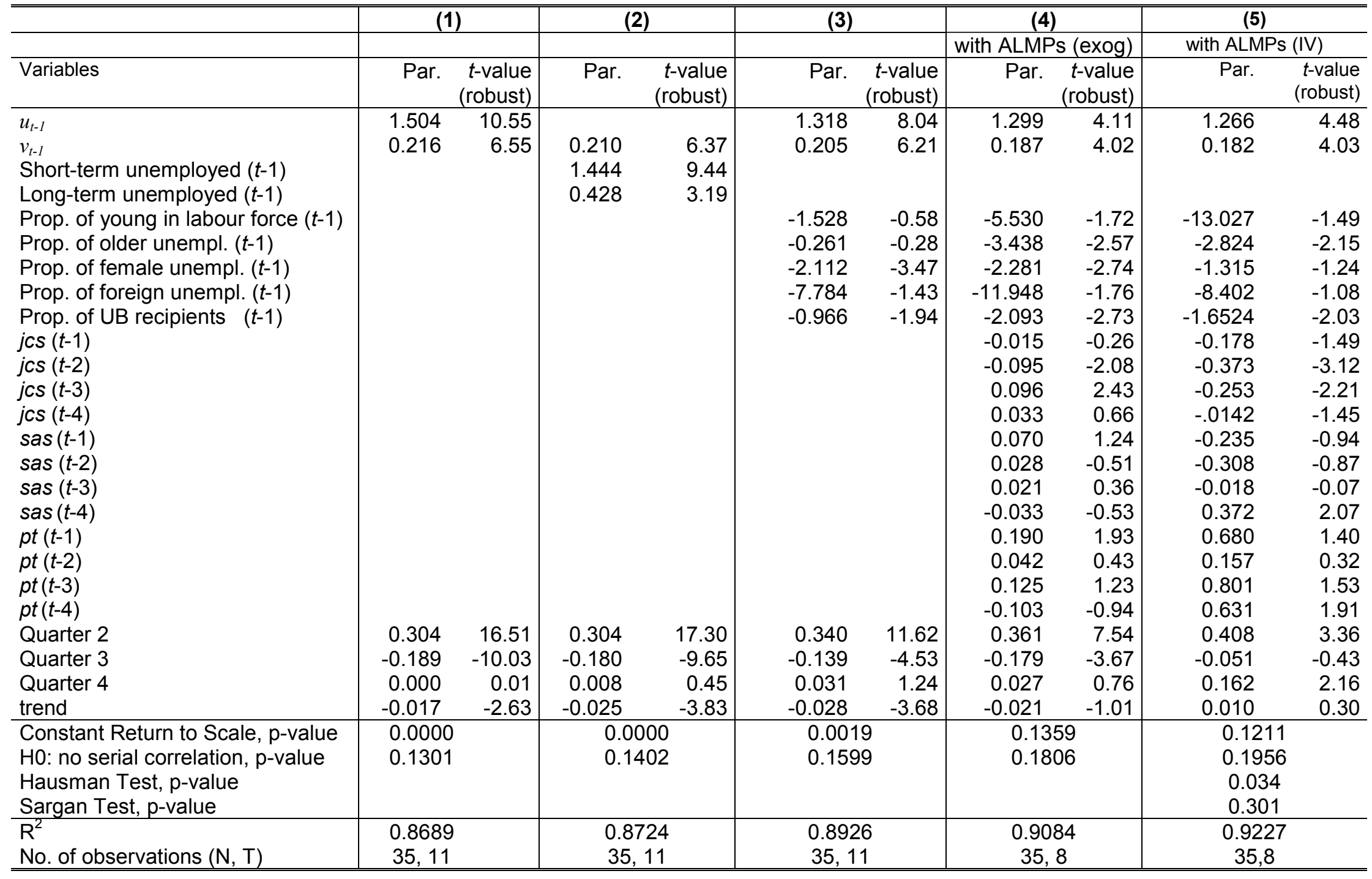


Table 3: Cumulated Elasticities of the Inflows into Regular Employment with Respect to participants in ALMP (robust $t$-values in parentheses)

\begin{tabular}{c|ccr|rrr}
\hline \hline & \multicolumn{3}{|c|}{ Treated as exogenous } & \multicolumn{3}{c}{ Instrumented } \\
\hline Cumulated effects & $J C S$ & $S A S$ & $P T$ & $J C S$ & $S A S$ & $P T$ \\
\hline$t-1$ & -0.002 & 0.089 & 0.175 & -0.178 & -0.235 & 0.680 \\
& $(-0.04)$ & $(1,58)$ & $(1.87)$ & $(-1.49)$ & $(-0.94)$ & $(1.40)$ \\
$t-2$ & -0.090 & 0.080 & 0.230 & -0.551 & -0.543 & 0.836 \\
& $(-1.38)$ & $(1.13)$ & $(1.77)$ & $(-2.64)$ & $(-1.06)$ & $(0.94)$ \\
$t-3$ & 0.004 & 1.53 & 0.470 & -0.804 & -0.560 & 1.637 \\
& $(0.05)$ & $(1.86)$ & $(3.05)$ & $(-2.64)$ & $(-0.93)$ & $(1.26)$ \\
$t-4$ & 0.062 & 0.030 & 0.486 & -0.947 & -0.189 & 2.268 \\
& $(0.61)$ & $(0.28)$ & $(2,42)$ & $(-2.45)$ & $(-0.27)$ & $(1.49)$ \\
\hline \hline
\end{tabular}

Notes: Calculated from the estimation results depicted in column (4) and (5) in Table 2.

\subsection{Augmented Beveridge Curve - Effects on Job Seeker Rate}

A Beveridge curve augmented by variables for ALMP may be derived as follows (see also CALMFORS and SKEDINGER, 1995). In a steady state equilibrium the number of separations equals the number of matches. Holding the separation rate constant and rearranging (2) one obtains the regression equation (see NICKELL et al., 2002; WALL and ZOEGA, 2002; FRANZ and SMOLNY, 1994; BÖRSCH-SUPAN, 1991)

$$
u_{i t}=\beta v_{i t}+\delta t+\gamma S+\eta_{i}+\varepsilon_{i t} .
$$

This equation can be augmented by ALMP and other variables affecting local unemployment. ALMP variables are introduced by so called accommodation ratios as proposed by CALMFORS and SKEDINGER (1995) ${ }^{30}$

$$
\operatorname{accr}_{i t}^{J C S}=\ln \left(P_{i t}^{J C S} / U_{i t}+P_{i t}^{J C S}+P_{i t}^{S A S}+P_{i t}^{P T}+P_{i t}^{\text {others }}\right)
$$

and for $S A S$ and $P T$ accordingly. Using accomodation ratios may be a first attempt to reduce the endogeneity problem of ALMP with respect to the unemployment rate.

In order to avoid "bookkeeping"-effects which are based on the fact that participants are not registered as unemployed, the unemployment rate $u_{i t}$ is extended to the job seeker rate by adding the stock of participants in ALMP

$$
j S r_{i t}=\ln \left(J S R_{i t}\right)=\ln \left(\left(U_{i t}+P_{i t}^{J C S}+P_{i t}^{S A S}+P_{i t}^{P T}+P_{i t}^{\text {others }}\right) / L_{i t}\right) .
$$

In order to allow for sluggish adjustment and lags in the effects of the ALMPs, a dynamic specification is used. It can be written as

$30 P_{i t}^{\text {others }}$ is the stock of participants in two smaller ALMP programmes. The schemes are called „Beschäftigungshilfen für Langzeitarbeitslose“ and „Eingliederungszuschüsse“. 


$$
\begin{aligned}
C(L) j s r_{i t}= & A_{1}(L) a c c r_{i t}^{J C S}+A_{2}(L) a c c r_{i t}^{S A S}+A_{3}(L) a c c r_{i t}^{P T} \\
& +\sum_{k=1}^{K} B_{k}(L) x_{i t}^{k}+\delta t+\gamma S+\eta_{i}+\varepsilon_{i t}
\end{aligned}
$$

by defining polynomials in the lag operator $C(L)=1-c_{1} L-c_{2} L^{2}-\ldots-c_{12} L^{12}$, $A_{j}(L)=a_{j 0}-a_{j 1} L-a_{j 2} L^{2}-\ldots-a_{j 12} L^{12}$ and $B_{k}(L)=b_{k 0}-b_{k 1} L-b_{k 2} L^{2}-\ldots-b_{k 6} L^{6} . j$ represents the three programmes (JCS, SAS, PT). $x_{i t}^{k}$ is a vector of $k$ explanatory variables including $v_{i t}$.

A similar specification using the same data base can be found in HUJER et al. (2002). The main difference here is that monthly data instead of quarterly data are used, which implies a time dimension of 50 observations for 35 LEOAs. ${ }^{31}$ This may lead to more reasonable results and makes it possible to exploit the time dimension to achieve consistency with the GMM dynamic panel data estimator (see JUDSON and OWEN, 1999). Other differences are that a log-linear specification instead of a linear specification is estimated and that some additional explanatory variables describing the local labour market are included.

In order to get rid of the regional specific effects $\eta_{i}$, equation (6) is estimated in first differences. For the estimation the GMM dynamic panel data estimator proposed by ARELLANO and BOND (1991) is used and endogenous (ALMP) and pre-determined variables are instrumented by its lagged levels. ${ }^{32}$ Furthermore, the inclusion of additional external instruments was checked. Since no possible instrumental variables (variables on election results, welfare recipients) could significantly improve the Sargan test statistic, they were not included and identification is based solely on lagged levels. ${ }^{33}$ As pointed out by BOND (2002), using too many lagged levels as instrumental variables may result in overfitting bias. JUDSON and OWEN (1999) show that using a restricted number of instrumental variables does not reduce the performance of the estimator. Therefore, not all possible lagged levels are used as instrumental variables, and robustness checks with respect to the number of lagged levels are performed. The number of instrumental variables for the ALMP variables is truncated at $t$-13 (12 lagged levels) and $t$-4 (three lagged levels), respectively.

Another issue is, whether to use one-step or the efficient two-step estimator. For a large time series dimension (in comparison to the number of cross sections) JUDSON and OwEN (1999) show that the one-step GMM estimator outperforms the two-step estimator. Therefore, here only the one-step estimator (with robust standard errors) is applied.

In equation (6) the vector $x_{i t}^{k}$ includes the structure of the unemployed (proportion of women, disabled, foreigner, and blue-collar workers ${ }^{34}$ ) as well as the proportion of younger people in the labour force. Note that other variables describing the structure of the labour force turned out to be insignificant. The one period lags of these variables

$31 \quad$ HUJER et al. (2002) use $34 \times 12(N \times T)$ observations

32 HUJER et al. (2002) additionally apply the BLUNDELL and BOND (1998) system GMM estimator.

33 The difference in the Sargan test statistics in two models is asymptotically $\chi^{2}$ distributed (see Bond, 2002).

34 The proportion of blue-collar workers may serve as a proxy for lower skilled workers. The proportion of UB recipients turned out to be insignificant. 
are treated as predetermined. ${ }^{35}$ Some descriptive statistics can be found in Table A1 and $\mathrm{A} 2$ in the Appendix.

In addition, the vector $x_{i t}^{k}$ includes the national unemployment and vacancy rate as well as the regional vacancy rate. The regional vacancy rate is likely to be simultaneously determined with the regional unemployment rate. Thus also the one month lagged regional vacancy rate is treated as predetermined, i.e. it is instrumented by lagged levels. The lagged national vacancy and unemployment rate are treated as strictly exogenous. In order to analyse a broader definition of regional unemployment the number of short-time workers is added to the JSR in an alternative specification. ${ }^{36}$

With 50 months for each LEOA, there is a substantial time dimension. This may render nonstationarity to an important issue. Testing for nonstationarity and cointegration in panel data has just recently became possible, due to methodological progress within the last years. ${ }^{37}$ Nonstationarity may be for the used estimator by ARRELANO and BOND (1991) a problem since the instrumentation strategy implies that lagged differences are regressed on lagged levels. In this paper augmented Dickey-Fuller unit root tests as proposed by SARNO and TAYLOR (1998) and TAYLOR and SARNO (1998) are performed. Under the null hypothesis the time series of all cross sections (LEOAs) are nonstationary. The test should, however, be interpreted with care, due to the definition of null hypothesis: If only one time series is stationary the null hypothesis is rejected. Nevertheless, the test may be at least interpreted as first evidence against nonstationarity. ${ }^{38}$ The Dickey-Fuller regression is performed for one up to 12 lag orders. The results are depicted in Table A5 in the Appendix. For all variables and lag orders the null hypothesis of a unit root is rejected.

The estimation results of equation (6) are depicted in Table A6 in the Appendix. The Sargan tests come from the corresponding homoscedastic estimator since the asymptotic distribution is only valid in the case of i.i.d. errors (see ARRELANO and BOND, 1991: 290). The Sargan tests of all specifications indicate that the validity of the instrumental variables cannot be rejected. Also the tests on second order autocorrelation in the residuals do not reject the null hypothesis in any specification. In column (1) the preferred specification is depicted which uses 12 lagged levels as instrumental variables. In column (2) the number of short-time workers is included in jsr. In column (3) only 3 lagged levels are used as instruments. The instrumentation strategy does hardly change any coefficient. ${ }^{39}$

The interpretation of the estimated coefficients is, due to the lagged dependent and explanatory variables, not straightforward. The elasticity of the job seeker rate with respect to the stock of ALMP participants has to be calculated in the same manner as in autoregressive distributed lag time-series models (see GREENE, 2000 and the expla-

The proportion of specific groups in the pool of unemployed may be affected by the level of unemployment.

Short-time work refers to the arrangements for working less than normal hours. In return for subsidies by the employment office, employers agree to avoid redundancies.

See the Special Issue of the Oxford Bulletin of Economics and Statistics Vol. 61(4) in 1999.

The main motivation for testing for unit root in a panel instead of single time series is that the power of the test increases with an increase in the number of cross-sections. TAYLOR and SARNO (1998) claim that the test is much more powerful than the univariate Augmented Dickey Fuller test.

39 There were many more robustness checks performed. For example omitting some of the variables in $x_{i t}^{k}$. The results turn out to be quite robust.
} 
nation in HUJER et al., 2002). In Table 4 the cumulated elasticities are depicted for the first 3 months (interpreted as 'short-term effect') and for the long-run effect. The associated standard errors are calculated by the delta method (see GREENE, 2000).

It can be seen in Table 4 that there are significantly negative short-term effects of $S A S$ and $P T$ but no significant effects in the long-run for any specification. Including the short-time workers implies no noticeable change in the long-term effects. While the insignificant cumulated long-term effect is in line with microeconometric studies, the interpretation of the significantly negative three months short-term effect of $S A S$ is, given potential locking-in effects and the evidence from micro studies, unexpected. ${ }^{40}$ Somehow, comparable results are found in the aggregate study by HUJER et al. (2002) for East Germany. A possible explanation is that employees at risk of becoming unemployed may participate in $S A S$. The associated temporary decrease in average wage costs at local labour markets may prevent or at least delay inflows into unemployment. This hypothesis would also explain the stronger effect if short-time work is included in the JSR: Short-time work can be prevented if the total wage costs are reduced by other subsidises from the employment office.

Table 4: Cumulated elasticities of the $J S R$ with respect to the ALMP accommodation ratios (robust $t$-values in parentheses)

\begin{tabular}{|c|c|c|c|c|c|c|}
\hline $\begin{array}{l}\text { Dep. } \\
\text { variable }\end{array}$ & $\begin{array}{l}\text { Number of lagged } \\
\text { levels as instruments }\end{array}$ & $\begin{array}{c}\text { Accomo- } \\
\text { dation } \\
\text { Ratio }\end{array}$ & $\begin{array}{l}\text { 2th order } \\
\text { serial cor- } \\
\text { relation } \\
\text { (p-value) }\end{array}$ & $\begin{array}{l}\text { Sargan Test } \\
\text { (p-value) }\end{array}$ & $\begin{array}{l}3 \text { months } \\
\text { cumulated } \\
\text { effect }\end{array}$ & $\begin{array}{l}\text { Long run } \\
\text { cumulated } \\
\text { effect }\end{array}$ \\
\hline \multirow[t]{3}{*}{$j s r$} & $\begin{array}{l}\text { lagged } j s r \text { and ALMP: } \\
t-2, \ldots, t-13\end{array}$ & JCS & & \multirow{3}{*}{$\begin{array}{r}\chi 2(4685)= \\
1180.80 \\
(1.000)\end{array}$} & $\begin{array}{l}0.001 \\
(0.16)\end{array}$ & $\begin{array}{l}-0.037 \\
(-0.68)\end{array}$ \\
\hline & $v_{i t}: t-1, \ldots, t-12$ & SAS & 0.340 & & $\begin{array}{l}-0.024 \\
(-2.46)\end{array}$ & $\begin{array}{l}-0.006 \\
(-0.16)\end{array}$ \\
\hline & $x_{i t}^{k}: t-1, \ldots, t-9$ & PT & & & $\begin{array}{l}-0.025 \\
(-1.59) \\
\end{array}$ & $\begin{array}{l}-0.008 \\
(-0.08)\end{array}$ \\
\hline \multirow{3}{*}{$\begin{array}{l}\text { jsr } \\
\text { incl. } \\
\text { short- } \\
\text { time } \\
\text { workers }\end{array}$} & $\begin{array}{l}\text { lagged } j s r \text { and ALMP: } \\
t-2, \ldots, t-13\end{array}$ & JCS & & \multirow{3}{*}{$\begin{array}{r}\chi 2(4685)= \\
1199.72 \\
(1.000)\end{array}$} & $\begin{array}{l}-0.004 \\
(-0.36)\end{array}$ & $\begin{array}{l}-0.027 \\
(-0.44)\end{array}$ \\
\hline & $v_{i t}: t-1, \ldots, t-12$ & SAS & 0.744 & & $\begin{array}{l}-0.042 \\
(-3.05)\end{array}$ & $\begin{array}{l}-0.074 \\
(-1.05)\end{array}$ \\
\hline & $x_{i t}^{k}: t-1, \ldots, t-9$ & $P T$ & & & $\begin{array}{l}-0.040 \\
-(2.83)\end{array}$ & $\begin{array}{l}-0.072 \\
(-0.72)\end{array}$ \\
\hline \multirow[t]{3}{*}{ jsr } & $\begin{array}{l}\text { lagged } j s r \text { and ALMP: } \\
t-2, \ldots, t-4\end{array}$ & JCS & & \multirow{3}{*}{$\begin{array}{r}\chi 2(2244)= \\
1180.80 \\
(1.000)\end{array}$} & $\begin{array}{l}0.001 \\
(0.12)\end{array}$ & $\begin{array}{l}-0.037 \\
(-0.64)\end{array}$ \\
\hline & $v_{i t}: t-1, \ldots, t-3$ & $S A S$ & 0.340 & & $\begin{array}{l}-0.020 \\
(-2.46)\end{array}$ & $\begin{array}{l}-0.006 \\
(-0.14)\end{array}$ \\
\hline & $x_{i t}^{k}: t-1, \ldots, t-3$ & $P T$ & & & $\begin{array}{l}-0.024 \\
(-1.59)\end{array}$ & $\begin{array}{l}-0.008 \\
(-0.07)\end{array}$ \\
\hline
\end{tabular}

Notes: Calculated from the estimation results depicted in Table A6 in the Appendix. The number of internal instruments is with respect to the lagged dependent variable as well as the accomodation ratios of ALMP.

$40 \quad$ Note that negative effect means here a reduction of the job seeker rate. 


\subsection{Dynamic Labour Demand - Effects on Regular Employment}

A regional labour demand equation may be specified as

$$
n_{i t}^{r e g}=\alpha n_{i t-1}^{r e g}+\beta_{1} y_{i t}+\beta_{2} w_{i t}+\beta_{3} Z_{i t-1}+\beta_{4} p_{i t}^{1}+\beta_{5} p_{i t}^{3}+\beta_{6} p_{i t-1}^{1}+\beta_{7} p_{i t-1}^{3}+\gamma S+\eta_{i}+\varepsilon_{i t}
$$

where small types denote logarithm (see ISSERMAN et al., 1986).$^{41} n_{i t}^{\text {reg }}$ represents the level of regular employment in local area $i$ normalised with total labour force. ${ }^{42} y_{i t}$ is the regional output (gross value added), $Z_{i t-1}$ are variables describing the structure of the local labour market and $w_{i t}$ is the wage rate, measured as labour monthly wage bill per employee in the industry. Using only industry wages results from data availability and may be justified as follows. First, even in East Germany collective wage bargaining is still relevant. Wage agreements from manufacturing sectors often serve as models for other branches. Second, the manufacturing sector has become the driving force in the economic development in East Germany. Thus, positive employment dynamics in the manufacturing sector are often the prerequisite for job creation in other sectors. Nevertheless, one should keep in mind that the measurement error is likely to bias the estimated effect of $w_{i t}$. Unfortunately, as noted above, since data for $S A S$ are not available up to 1997, $S A S$ cannot not be included in the analysis. Therefore, only the effects of $J C S$ and $P T$ can be evaluated, which is indicated in (7) by the fact that only $p^{I}$ and $p^{3}$ are included. $p^{l}$ and $p^{3}$ represent the participants in $J C S$ and $P T$ relative to the labour force. ${ }^{43} S$ denotes a vector of (yearly) time dummies, $\eta_{i}$ are regional fixedeffects, and $\varepsilon_{i t}$ is a white noise error term.

Equation (7) is based on restrictive assumptions concerning the production process. Taking more factor prices into account, it would be possible to specify a more flexible labour demand equation based on industry cost minimisation (see for example TAYLOR, 1982). It was tried to calculate user cost of capital on district level, making use of regional variation in tax rates and investment grants (see FRANZ and SCHALK, 1995) as well as BÜTTNER, 1999). However, no attempts to include measures for capital user costs lead to significant parameter estimates. Therefore, only labour costs are included and it is assumed that other factor costs are captured by the fixed regional effects and fixed time dummies (see VAN REENEN, 1997).

The outstanding role of the manufacturing sector in the East German regional development is exactly the reason for introducing the proportion of manufacturing employees in $Z_{i t-1}$ as an explanatory variable. Further variables are the average number of employees in manufacturing establishments, the proportion of employees in farming and forestry, the proportion of highly skilled employees (university or polytechnic degree) in total employment, and the population density. Descriptive statistics can be found in Table A3 in the Appendix.

\footnotetext{
41 Comparable equations in time-series frameworks have been estimated by KRAFT (1998) as well as by JOHNSON and TOMOLA (1977).

42 This normalisation seems to be necessary in order to eliminate effects due to differences in the size of the regional labour markets. Normalisation with the regional population does not change the results to a large extent.

43 Also specifications where ALMP is introduced as accomodation ratios (see last section) are estimated. The results change only marginally. Results are available by the author on request.
} 
Using equation (7) the effects of ALMPs are estimated at a given output level which implies that productivity effects of ALMP are eliminated and pure crowding-out effects are estimated. Furthermore, possible regional multiplier-effects due to increased regional purchasing power as assumed by BLIEN et al. (2002) are not taken into account. Therefore, equation (7) is additionally estimated omitting the output variable in order to test whether there are significant employment effects of ALMPs via the regional output.

The estimation is performed again with the ARRELANO and BOND (1991) GMM estimator. Since there are now 101 local areas (districts) and five time periods (years), the two-step estimator is applied. Since the two-step estimator is known to lead to an underestimation of the standard errors, for the preferred specification also the one-step results (with robust standard errors) are displayed. Note, that the first-differencing and the lagged dependent variable each lead to a reduction of one period. The resulting number of periods is therefore three.

The estimation results can be seen in Table 5. In column (1) of Table 5 all variables except for the lagged endogenous variable are treated as strictly exogenous. An unexpected result is the positive coefficient of the wage variable, which is, however, not statistically significant. There are at least three explanations for this result: As the variable includes only the wage for the industry, the measurement error may bias the estimated effect towards zero. Employment and wages may be determined simultaneously as suggested by some wage bargaining models. Migration between regions is not modelled in the estimation. Economic theory suggests that workers migrate to states in order to increase their wages, which in turn raises employment (see TOPEL, 1986). For these reasons wages cannot be treated as uncorrelated with the error term and are, therefore, treated as endogenous and instrumented with its lagged levels. The Sargan test in column (1) indicates that this specification is to be preferred. Note that in all specifications, except the first one in column (1), the null hypothesis of valid instrument cannot be rejected. Furthermore, the null hypothesis of no second-order serial correlation cannot be rejected in any specification. In the specification column (3) also the ALMP variables are treated as endogenous and are instrumented by lagged levels. In the specification in column (4) the proportion of votes for liberal-conservative parties is used as an additional instrument. Other possible instrumental variables discussed in section 5.1 do not cause an increase in the Sargan test statistic. In column (5) the results of the one-step estimator with robust standard errors are depicted. ${ }^{44}$ In column (6) the regional output is omitted using the two step-estimator. ${ }^{45}$ It can be seen that the other coefficients are hardly affected.

In most specifications the lagged proportion of manufacturing sector employees have positive impact which is in line with the hypothesis that this sector is the driving-force for economic upturn in East Germany. Also a higher share of highly-skilled workers has a positive impact which underlines the importance of human capital for regional development. The average number of employees per establishment in manufacturing

\footnotetext{
44 The Sargan test for the one-step specification comes again from the corresponding homoscedastic estimator.

45 The results of the one-step estimator are comparable. Results are available on request by the author.
} 
has a negative impact which is in line with previous results (see BÜTTNER, 1999 for further discussions).

The resulting long-term elasticities are depicted in Table 6. As already discussed, the wage elasticity is negative in specification where the wage variable is instrumented. After instrumentation, the long-term wage elasticity is approximately between 12 and 17 per cent, which seems to be - given that the public sector is included - reasonable. Likewise reasonable is the long-term output elasticity which is between 37 and 44 per cent.

The estimated effects of ALMP on regular employment can be summarised as follows. JCS have a negative long-term effect on regular employment: A long-term increase of the participants in JCS by 1 per cent leads to a reduction of regular employment by 0.06 up to 0.1 per cent, which is moderate in comparison to magnitudes found in other studies on subsidised employment in the public sector (see CALMFORS et al. 2001). $P T$ seems to have no significant long-term effects. There seems to be a negative contemporaneous effect in $t$, which vanishes in $t$-1. Column (6) indicates that excluding output does not change the results to a large extent. This may be interpreted as evidence that ALMP has no strong employment effects via the regional output. 
Table 5: Demand for Regular Labour in East German Districts

\begin{tabular}{|c|c|c|c|c|c|c|c|c|c|c|c|c|}
\hline \multirow[b]{3}{*}{ Variable } & \multicolumn{2}{|c|}{ (1) } & \multicolumn{2}{|c|}{$(2)$} & \multicolumn{2}{|c|}{ (3) } & \multicolumn{2}{|c|}{ (4) } & \multicolumn{2}{|c|}{ (5) } & \multicolumn{2}{|c|}{ (6) } \\
\hline & \multicolumn{2}{|c|}{$\begin{array}{c}\text { Two-step GMM } \\
\text { all variables ex- } \\
\text { ogenous }\end{array}$} & \multicolumn{2}{|c|}{$\begin{array}{l}\text { Two-step GMM } \\
\text { IV for wages }\end{array}$} & \multicolumn{2}{|c|}{$\begin{array}{c}\text { Two-step GMM } \\
\text { IV for ALMP and } \\
\text { wages }\end{array}$} & \multicolumn{2}{|c|}{$\begin{array}{c}\text { Two-step GMM } \\
\text { IV for ALMP and } \\
\text { wages } \\
\text { - external IV }\end{array}$} & \multicolumn{2}{|c|}{$\begin{array}{c}\text { One-step GMM - } \\
\text { IV for ALMP and } \\
\text { wages } \\
\text { - external IV }\end{array}$} & \multicolumn{2}{|c|}{$\begin{array}{c}\text { Two-step GMM } \\
\text { IV for ALMP and } \\
\text { wages } \\
\text { - external IV } \\
\text { no output }\end{array}$} \\
\hline & Param. & $t$-value & Param. & $t$-value & Param. & $t$-value & Param. & $t$-value & Param. & $\begin{array}{r}t \text {-value } \\
\text { (robust) }\end{array}$ & Param. & $t$-value \\
\hline$n_{i t-1}$ & 0.139 & 1.09 & 0.156 & 2.02 & 0.112 & 1.88 & 0.116 & 2.08 & 0.109 & 1.71 & 0.158 & 2.66 \\
\hline$y_{i t}$ & 0.340 & 3.50 & 0.366 & 3.61 & 0.387 & 4.03 & 0.392 & 3.99 & 0.326 & 3.52 & - & \\
\hline$w_{i t}$ & 0.059 & 1.25 & -0.099 & -1.92 & -0.123 & -2.39 & -0.117 & -2.62 & -0.154 & -2.07 & -0.133 & -3.11 \\
\hline Prop. of Agriculture $(t-1)$ & -0.402 & -1.79 & -0.258 & -1.21 & -0.095 & -0.41 & -0.073 & -0.30 & -0.044 & -0.09 & -0.006 & -0.02 \\
\hline Prop. of Manufacturing $(t-1)$ & 0.584 & 2.41 & 0.835 & 3.34 & 0.579 & 2.42 & 0.500 & 2.41 & 0.704 & 2.32 & 1.002 & 4.94 \\
\hline Prop. of highly skilled $(t-1)$ & 1.432 & 3.37 & 1.225 & 2.90 & 0.929 & 2.32 & 0.913 & 2.36 & 0.704 & 2.32 & 0.493 & 1.27 \\
\hline Av. no. of workers establ. ${ }^{*} 10^{-3}(t-1)$ & -0.193 & -1.13 & -0.410 & -2.65 & -0.449 & -3.77 & -0.487 & -4.35 & -0.438 & -2.06 & -0.125 & -4.78 \\
\hline Population Density $(t-1)$ & -0.060 & -2.37 & -0.061 & -3.41 & -0.063 & -4.75 & -0.060 & -4.62 & -0.055 & -1.39 & -0.074 & -3.89 \\
\hline$j c s(t)$ & 0.017 & 1.39 & 0.010 & 0.92 & -0.008 & -0.44 & -0.013 & -0.71 & 0.001 & -0.01 & -0.024 & -1.63 \\
\hline$j c s(t-1)$ & -0.014 & -1.39 & -0.020 & -2.10 & -0.070 & -4.56 & -0.072 & -4.89 & -0.046 & -2.14 & -0.058 & -4.68 \\
\hline$f b w(t)$ & 0.010 & 0.67 & 0.021 & 1.38 & -0.037 & -1.08 & -0.059 & -2.01 & -0.036 & -0.69 & -0.043 & -1.40 \\
\hline fbw $(t-1)$ & 0.009 & 0.79 & 0.006 & 0.59 & 0.021 & 1.18 & 0.025 & 1.51 & 0.004 & 0.16 & 0.068 & 3.40 \\
\hline Year 1999 & -0.005 & -0.95 & -0.013 & -2.51 & -0.008 & -1.08 & -0.010 & -1.30 & -0.003 & -0.2 & -0.014 & -2.15 \\
\hline Year 2000 & -0.022 & -1.71 & -0.034 & -2.72 & -0.043 & -2.05 & -0.047 & -2.30 & -0.029 & -0.79 & -0.039 & -4.52 \\
\hline Constant & -0.015 & -1.73 & -0.005 & -0.57 & 0.001 & 0.06 & 0.001 & 0.06 & -0.006 & -0.39 & 0.001 & 0.22 \\
\hline Sargan test, $p$-value & \multirow{2}{*}{\multicolumn{2}{|c|}{0.0159}} & \multicolumn{2}{|c|}{0.2254} & \multirow{2}{*}{\multicolumn{2}{|c|}{0.5038}} & \multicolumn{2}{|c|}{0.5627} & \multicolumn{2}{|c|}{0.7648} & \multicolumn{2}{|c|}{0.3341} \\
\hline 1 st order serial correlation, $p$-value & & & \multirow{2}{*}{\multicolumn{2}{|c|}{0.7449}} & & & \multirow{2}{*}{\multicolumn{2}{|c|}{0.8068}} & \multicolumn{2}{|c|}{0.8471} & \multicolumn{2}{|c|}{0.7747} \\
\hline 2 st order serial correlation, $p$-value & \multicolumn{2}{|c|}{0.6322} & & & \multicolumn{2}{|c|}{0.7962} & & & & & & \\
\hline No. of Observations $(N, T)$ & \multicolumn{2}{|c|}{101,3} & \multicolumn{2}{|c|}{101,3} & \multicolumn{2}{|c|}{101,3} & \multicolumn{2}{|c|}{101,3} & \multicolumn{2}{|c|}{101,3} & \multicolumn{2}{|c|}{101,3} \\
\hline
\end{tabular}


Table 6: Estimated Long-Run Elasticities ( $t$-values)

\begin{tabular}{|c|c|c|c|c|c|c|}
\hline & (1) & (2) & (3) & (4) & (5) & (6) \\
\hline & $\begin{array}{l}\text { all variables } \\
\text { exogeneous }\end{array}$ & IV for wages & $\begin{array}{l}\text { IV for } A L M P \\
\text { and wages }\end{array}$ & $\begin{array}{l}I V \text { for } A L M P \\
\text { and wages } \\
\text { - external IV }\end{array}$ & $\begin{array}{c}\text { IV for ALMP } \\
\text { and wages } \\
\text { - external IV }\end{array}$ & $\begin{array}{c}\text { IV for ALMP } \\
\text { and wages } \\
\text { - external IV } \\
\text { no output }\end{array}$ \\
\hline output & $\begin{array}{l}0.395 \\
(3.23)\end{array}$ & $\begin{array}{l}0.434 \\
(3.66)\end{array}$ & $\begin{array}{l}0.436 \\
(4.04)\end{array}$ & $\begin{array}{l}0.443 \\
(4.03)\end{array}$ & $\begin{array}{l}0.366 \\
(3.29)\end{array}$ & - \\
\hline wage & $\begin{array}{l}0.069 \\
(1.20)\end{array}$ & $\begin{array}{l}-0.117 \\
(-2.05)\end{array}$ & $\begin{array}{l}-0.138 \\
(-2.54)\end{array}$ & $\begin{array}{l}-0.133 \\
(-2.84)\end{array}$ & $\begin{array}{l}-0.173 \\
(-2.40)\end{array}$ & $\begin{array}{l}-0.158 \\
(-3.50)\end{array}$ \\
\hline$j c s(\mathrm{t})$ & $\begin{array}{l}0.020 \\
(1.36)\end{array}$ & $\begin{array}{l}0.012 \\
(0.92)\end{array}$ & $\begin{array}{l}-0.009 \\
(-0.44)\end{array}$ & $\begin{array}{l}-0.015 \\
(-0.72)\end{array}$ & $\begin{array}{l}-0.001 \\
(-0.01)\end{array}$ & $\begin{array}{l}-0.029 \\
(-1.67)\end{array}$ \\
\hline$p t(\mathrm{t})$ & $\begin{array}{l}0.012 \\
(0.67)\end{array}$ & $\begin{array}{l}0.025 \\
(1.36)\end{array}$ & $\begin{array}{l}-0.042 \\
(-1.10)\end{array}$ & $\begin{array}{l}-0.066 \\
(-2.04)\end{array}$ & $\begin{array}{l}-0.041 \\
(-0.69)\end{array}$ & $\begin{array}{l}-0.051 \\
(-1.41)\end{array}$ \\
\hline$j c s(t)+j c s(t-1)$ & $\begin{array}{l}0.003 \\
(0.16)\end{array}$ & $\begin{array}{l}-0.011 \\
(-0.55)\end{array}$ & $\begin{array}{l}-0.088 \\
(-3.24)\end{array}$ & $\begin{array}{l}-0.096 \\
(-3.45)\end{array}$ & $\begin{array}{l}-0.052 \\
(-1.95)\end{array}$ & $\begin{array}{l}-0.098 \\
(-4.10)\end{array}$ \\
\hline$p t(t)+p t(t-1)$ & $\begin{array}{l}0.022 \\
(0.95)\end{array}$ & $\begin{array}{l}0.032 \\
(1.40)\end{array}$ & $\begin{array}{l}-0.018 \\
(-0.52)\end{array}$ & $\begin{array}{l}-0.038 \\
(-1.26)\end{array}$ & $\begin{array}{l}-0.036 \\
(-0.08)\end{array}$ & $\begin{array}{r}0.029 \\
(1.00)\end{array}$ \\
\hline
\end{tabular}

Notes: Calculated from the estimation results in Table 5. The columns correspond to the columns in Table 5.

\section{Conclusion}

Due to potential indirect effects of ALMP on non-participants, evaluation of ALMP using aggregate data in addition to micro data is crucial. The larger a programme is, the more likely are indirect effects to occur. For this reason evaluation based on aggregate data seems to be essential in East Germany, where a large proportion of the labour force participate in ALMPs.

Similar to microeconometric studies, aggregate evaluation studies are associated with fundamental methodological problems: ALMP cannot be treated as exogenous with respect to the local labour market condition. This has to be taken into account in order to obtain an unbiased estimate of effect of ALMP.

In this paper the three largest active labour market policy (ALMP) programmes - job creation schemes (JCS), structural adjustment schemes $(S A S)$ and public training measures $(P T)$ - are evaluated. $J C S$ and $S A S$ are subsidised jobs, mostly implemented in the non-profit sector. The analysis of the regional allocation rule of the funding of ALMPs reveals that ALMP cannot be treated as exogenous with respect to the local labour market situation which makes the use of suitable econometric approaches necessary. Three different approaches based on different econometric techniques for panel data (GMM and two-stage least squares) and two different regional data sets are used.

The augmented matching function indicates negative effects of $J C S$ on matching efficiency and no significant effects of $P T$ and $S A S$. This result is in line with available microeconometric research. A reduced form approach based on the Beveridge curve does not indicate any long-term effects of ALMPs on regional job seeker rates. There are some short-term effects indicating that $S A S$ reduces transitionally the job seeker rate. A possible explanation is that it may reduce average wage costs in the short-run 
and lead therefore to a temporary stabilisation of employment. However, more research seems to be necessary into this issue. Dynamic labour demand estimations, based on district level data, indicate that $P T$ has no effects on employment and JCS leads to displacement of regular employment.

Of course, deriving political implications based on the empirical evidence in this paper seems not to be appropriate. However, taking all the unpleasant results of available micro studies into account, one can state that a radical reform of the East German ALMP and especially of $J C S$ seems to be urgent. An interesting question which may provide additional political implications is how the differences in the results of JCS and $S A S$ can be explained. This is, however, a topic for further research. Another issue for further research is to take labour market participation, migration, and spill-over effects within more structural models into account. 


\section{References}

Anderson, T. W. and C. Hsiao (1981), Estimation of dynamic models with error components, Journal of the American Statistical Association 76, 598-606.

Arrelano, M. and S. Bond (1991), Some Tests of Specification for Panel Data: Monte Carlo Evidence and an Application to Employment Equations, Review of Economics Studies 58, 277-297.

Atkinson, A. B. and J. Micklewright (1991), Unemployment compensation and labor market transitions: a critical review; Journal of Economic Literature 24, 1679-1727.

Baltagi, B. (2001), Econometric Analysis of Panel Data, 2. ed., Chichester.

Bergemann A., B. Fitzenberger, B. Schultz und S. Speckesser (2000), Multiple Active Labor Market Policy Participation in East Germany: An Assessment of Outcomes, Konjunkturpolitik, Suppl. 51, 195-244.

Bellmann. L. and R. Jackman (1996), Aggregate Impact Analysis, in: Schmid. G., J. O'Reilly and K. Schömann (Eds.), International Handbook of Labour Market Policy and Evaluation, Cheltenham, 143-162.

Blanchard, O .J. and P. Diamond (1994), Ranking, Unemployment Duration, and Wages, Review of Economic Studies 61, 417-434.

Blien, U. (2002), Ein Arbeitsmarktgesamtindikator zur regionalen Mittelverteilung für die aktive Arbeitsmarktpolitik, in: Kleinhenz, G. (Hrsg.), IAB-Kompendium Arbeitsmarkt- und Berufsforschung, BeitrAB, Bd. 250, 335-344.

Blien, U., E. Maierhofer, D. Vollkommer und K. Wolf (2002), Ostdeutschland - Effekte der Arbeitsmarktpolitik auf die regionale Beschäftigung, IAB Kurzbericht 13 (2.7.2002).

Blundell, R. and S. Bond (1998), Initial conditions and moment restrictions in dynamic panel data models, Journal of Econometrics 87, 115-143.

Boeri, T. and M.C. Burda (1996), Active Labor Market Policies, Job Matching and the Czech Miracle, European Economic Review 40, 805-817.

Börsch-Supan, A. H. (1991), Panel Data Analysis of the Beveridge Curve - Is there a macroeconomic relationship between the Rate of Unemployment and the Vacancy Rate, Economica 58 (231), 279297.

Bond, S. (2002), Dynamic Panel Data Models: A Guide to Micro Data Methods and Practice, Portuguese Economic Journal 1 (2), 141-162.

Büttner, T. (1999), Agglomeration, Growth, and Adjustment, ZEW Economic Studies, Vol. 2, Heidelberg.

Büttner, T. and H. Prey (1998), Does Active Labour Market Policy Affect Structural Unemployment? An Empirical Investigation for West German Regions, 1986 to 1993, Zeitschrift für Wirtschaftsund Sozialwissenschaften (ZWS) 118, 389-412.

Bundesanstalt für Arbeit (2003), Aufbau Ost-Der Beitrag der Bundesanstalt für Arbeit, Nürnberg.

Calmfors, L. (1994), Active Labour Market Policy and Unemployment - A framework for the Analysis of Crucial Design Features, OECD Economic Studies 22, 7-47.

Calmfors, L. (1995), What Can We Expect from Active Labour Market Policy?, Konjunkturpolitik 43, $11-30$.

Calmfors, L. and H. Lang, (1995), Macroeconomic Effects of Active Labour Market Programmes in a Union Wage-Setting, Economic Journal 105, 601-619.

Calmfors, L., and P. Skedinger, (1995), Does Active Labour Market Policy Increase Employment? Theoretical Considerations and Some Empirical Evidence from Sweden, Oxford Review of Economics 11 (1), 91-109.

Calmfors, L., A. Forslund and M. Hemström (2001), Does Active Labour Market Policy Work? Lessons from the Swedish Experiences, Swedish Economic Policy Review 2.

Cockx, B. and G. Ridder (2001), Social Employment of Welfare Recipients in Belgium: An Evaluation, Economic Journal 111, 322-352. 
Fay, R. (1996), Enhancing the Effectiveness of Active Labour Market Policies: Evidence from Programme Evaluations in OECD Countries, Labour Market and Social Policy Occasional Papers No. 18, OECD Paris.

Fertig, M. und C. M. Schmidt (2000), Discretionary Measures of Active Labor Market Policy: The German Employment Promotion Reform in Perspective, Schmollers Jahrbuch (Journal of Applied Social Science Studies) 120, 537-565.

Fertig, M, C. M. Schmidt and H. Schneider (2002), Active Labour Market Policy in Germany - Is there a Successful Policy Strategy, IZA Discussion Paper No. 576, Bonn.

Feist, H. und R. Schöb (2000), Hilfe zur Arbeit - Lehren aus dem Leipziger Modell, Wirtschaftsdienst 3/2000, 159-166.

Franz, W. and W. Smolny (1994), The Measurement and Interpretation of Vacancy Data and the Dynamics of the Beveridge-Curve: The German Case, in: Muysken, J. (ed.), Measurement and Analysis of Job Vacancies, Aldershot, 203-237.

Franz, W. und H.J. Schalk (1995), Eine kritische Würdigung der Wirksamkeit der regionalen Investitionsförderung in der Bundesrepublik Deutschland, in: Gahlen B., H. Hesse und H. Ramser (Hrsg.), Standort und Region. Neue Ansätze zur Regionalökonomik, Tübingen, 283-302.

Gerfin, M. and M. Lechner (2002), Microeconometric Evaluation of the Active Labour Market Policy in Switzerland, The Economic Journal 112, 854-893.

Greene, W. (2000), Econometric Analysis, Forth Edition, Prentice Hall.

Härdle, W. (1991), Applied nonparametric regression, 1. paperback ed., Cambridge.

Hagen, T. und V. Steiner (2000), Von der Finanzierung der Arbeitslosigkeit zur Förderung von Arbeit - Analysen und Handlungsempfehlungen zur Arbeitsmarktpolitik, ZEW Wirtschaftsanalysen, Bd. 51, Baden-Baden.

Heckman, J.J., R.J. Lalonde and J.A. Smith (1999), The Economics and Econometrics of Active Labor Market Programs, in: O. Ashenfelter und D. Card (Eds.), Handbook of Labour Economics, Vol. 3, Amsterdam, 1865-2097.

Heckman, J.J., J. Smith and N. Clements (1997), Making the Most out of Programme Evaluations and Social Experiments: Accounting for Heterogeneity in Programme Impacts, Review of Economic Studies 64, 487-535.

Hujer, R. und M. Caliendo (2001), Evaluation of Active Labour Market Policy - Methodological Concepts and Empirical Estimates, in: Becker, I., N. Ott und G. Rolf, (Hrsg.), Soziale Sicherung in einer dynamischen Gesellschaft, Frankfurt, 583-617.

Hujer, R., M. Caliendo and D. Radic (2002), Estimating the Effects of Wage Subsidies on the Labour Demand in West-Germany using the IAB-Establishment Panel, ifo-Studien 47 (2), 163-197.

Hujer, R., U. Blien, M. Caliendo and C. Zeiss (2002), Macroeconometric Evaluation of Active Labour Market Policy in Germany - A Dynamic Panel Approach Using Regional Data, IZA Discussion Paper No. 616, Bonn.

Hujer, R., M. Caliendo and S. Thomsen (2003), New Evidence on the Effects of Job Creation Schemes in Germany - A Matching Approach with Threefold Heterogeneity, University of Frankfurt Working Paper, Frankfurt.

Hunt, J. (1995), The Effect of Unemployment Compensation on Unemployment Duration in Germany, Journal of Labour Economics 13 (1), 88-120.

Isserman, A., C. Taylor, S. Gerking and U. Schubert (1986), Regional Labor Markets, in: P. Nijkamp (ed.), Handbook of Regional and Urban Economics, Vol. I, 543-580.

Johnson, G. and J. Tomola (1977), Fiscal substitution effects of alternative approaches to public service employment, Journal of Human Resources 12, 3-26.

Judson, R.A. and A. L. Owen (1999), Estimating Dynamic Panel Data Models: a Guide for Macroeconomists, Economic Letters 65, 9-15.

Kraft, K. (1998), An Evaluation of Active and Passive Labour Market Policy, Applied Economics 30, 783-793. 
Lechner, M. (2001), Identification and Estimation of Causal Effects of Multiple Treatments under the Conditional Independence Assumption, in: Lechner, M. and F. Pfeiffer (eds), Econometric Evaluation of Labour Market Policies, Heidelberg, 43-58.

Lehmann, H. (1995), Active Labor Market Policies in the OECD and in Selected Transition Economies, World Bank Policy Research Working Paper No.1502, Washington D.C..

Martin, J.P. (2000), What Works among Active Labour Market Policies: Evidence from OECD Countries' Experiences, OECD Economic Studies 30 (1), 79-113.

Machin, S. and A. Manning (1999), The Causes and Consequences of Longterm Unemployment in Europe, in: O. Ashenfelter and D. Card (Eds.), Handbook of Labour Economics, Vol.. 3, Amsterdam, 3085-3139.

Münich, D., J. Svejnar and K. Terrell (1998), The Worker-Firm Matching in Transition Economies: (Why) Are the Czechs More Sucessfull Than Others?, Working Paper No. 107, William Davidson Institute at the University of Michigan Business School.

Nickell, S., L. Nunziata, W. Ochel and G. Quintini (2002), The Beveridge Curve, Unemployment and Wages in the OECD from the 1960 to the 1990s, in: Phelps E. S. and P. Aghion (Eds.), Knowledge, information, and expectations in modern macroeconomics, 394-431.

Puhani, P. (1999), Evaluating Active Labour Market Policies, ZEW Economic Studies, Vol. 5, Heidelberg.

Pannenberg, M. and J. Schwarze (1996), Unemployment, Labor Market Training Programs and Regional Wages: An Extended Wage Curve Approach, DIW-Diskussionspapiere No. 139, Berlin.

Petrongolo, B. and C. A. Pissarides (2001), Looking into the Black Box: A Survey of the Matching Function, Journal of Economic Literature XXXIX (June), 390-431.

Pissarides, C.A. (2000), Equillibrium Unemployment Theory, MIT Press.

Prey, H. (1999), Wirkungen staatlicher Qualifizierungsmaßnahmen - Eine empirische Untersuchung für die Bundesrepublik Deutschland, Schriftenreihe des Forschungsinstituts für Arbeit und Arbeitsrecht an der Universität St. Gallen, Bd. 19, Bern.

Rubin, D. (1980), Comment of Badu, D. - Randomization Analysis of Experimental Data: The Fisher Randomization Test, Journal of the American Statistical Association 75, 591-593.

Sarno, L. and M. P. Taylor (1998), Real exchange rates under the current float: unequivocal evidence of mean reversion, Economics Letters 60, 131-137.

Schmid G., S. Speckesser and C. Hilbert (2001), Does Active Labour Market Policy Matter? An Aggregate Analysis for Germany, in: de Koning J. and H. Mosley (Eds.), Labour Market Policy and Unemployment. An Evaluation of Active Measures in France, Germany, the Netherlands, Spain and Sweden, Cheltenham, 77-114.

Steiner, V. (1997), Extended Benefit-Entitlement Periods and the Duration of Unemployment in West Germany, ZEW Discussion Paper No. 97-14, Mannheim.

Steiner, V. (2001), Unemployment Persistence in the West German Labour Market: Negative Duration Dependence or Sorting?, Oxford Bulletin of Economics and Statistics 63 (1), 91-113.

Steiner, V., E. Wolf, J. Egeln, M. Almus, H. Schrumpf und P. Feldotto (1998), Strukturanalyse der Arbeitsmarktentwicklung in den neuen Bundesländern, ZEW Wirtschaftsanalysen, Bd. 30, BadenBaden.

Steiner, V. und T. Hagen (2002), Was kann die Aktive Arbeitsmarktpolitik in Deutschland aus der Evaluationsforschung in anderen europäischen Ländern lernen?, Perspektiven der Wirtschaftspolitik 3 (2), 189-206.

Taylor, C.A. (1982), Econometric Modelling of Urban and Other Substate Areas, Regional Science and Urban Economics 12, 425-448.

Taylor, M. P. and L. Sarno (1998), The behavior of real exchange rates during the post-Bretton Woods period, Journal of International Economics 46, 281-312.

Topel, R.H. (1986), Local Labor Markets, Journal of Political Economy 94 (3), 111-143.

Van Ours, J. (2002), The Locking-in Effect of Subsidized Jobs, CentER Discussion Paper No. 2002-60. 
Van Reenen, J. (1997), Employment and Technological Innovation: Evidence from U.K. Manufacturing Firms, Journal of Labor Economics 15(2), 255-284.

Wall, H.J. and G. Zoega (2002), The British Beveridge Curve: A Tale of Ten Regions, Oxford Bulletin of Economics and Statistics 64 (3), 261-280.

Wooldridge, J.M. (2002), Econometric analysis of cross section and panel data, Cambridge. 


\section{Appendix}

Table A1: Sample Statistics Beveridge Curve Approach (non-weighted, percentages)

\begin{tabular}{l|rrrr}
\hline \hline & Mean & $\begin{array}{c}\text { Standard } \\
\text { Deviation }\end{array}$ & Min & Max \\
\hline Rate of open unemployment & 17.88 & 2.68 & 11.70 & 26.01 \\
JSR & 23.01 & 3.49 & 15.82 & 33.01 \\
Short-time workers relative to labour force & 0.41 & 0.51 & 0.02 & 8.36 \\
Accomodation ratio JCS & 6.59 & 2.77 & 1.618 & 19.07 \\
Accomodation ratio SAS & 4.25 & 2.08 & 0.152 & 12.52 \\
Accomodation ratio PT & 7.74 & 1.39 & 4.172 & 12.27 \\
\hline \hline
\end{tabular}

Notes: Non-weighted sample statistic for the specification (1) in Table A6. 35 monthly LEOA data from February 2000 until January 2003.

Table A2: Sample Statistics Matching Function (non-weighted, percentages)

\begin{tabular}{l|rrrr}
\hline \hline & Mean & $\begin{array}{r}\text { Standard } \\
\text { Deviation }\end{array}$ & Min & Max \\
\hline Inflows into Employment (all types)* & 4.70 & 1.18 & 2.37 & 7.72 \\
Inflows into JCS and SAS* $^{*}$ & 0.26 & 0.13 & 0.05 & 0.80 \\
Open unemployment $^{*}$ & 17.44 & 2.59 & 12.11 & 23.67 \\
Registered vacancies* $^{*}$ & 0.85 & 0.29 & 0.27 & 1.73 \\
Participants in JCS $^{*}$ & 1.72 & 0.75 & 0.47 & 5.03 \\
Participants in SAS* & 1.03 & 0.48 & 0.23 & 2.30 \\
${\text { Participants in } P T^{*}}_{\text {Prop. of young in labour force }(<25){ }^{*}}$ & 1.84 & 0.44 & 0.94 & 3.07 \\
Prop. of older unemployed ( $\geq 55)$ & 12.66 & 1.02 & 9.60 & 14.88 \\
Prop. of female unemployed & 28.43 & 2.99 & 20.97 & 35.02 \\
Prop. of foreign unemployed & 51.88 & 3.53 & 41.60 & 59.16 \\
Prop. of unemployed with UB & 1.99 & 2.72 & 0.69 & 17.62 \\
\hline \hline
\end{tabular}

Notes: Non-weighted sample statistic for the specification (5) in Table 2. 35 quarterly LEOA data from the second quarter 2000 until the first quarter 2002. * relative to total labour force. 
Table A3: Sample Statistics Demand for Regular Labour (non-weighted, percentages)

\begin{tabular}{l|rrrr}
\hline \hline & Mean & $\begin{array}{r}\text { Standard } \\
\text { Deviation }\end{array}$ & Min & Max \\
& & & \\
\hline Employment (total) * & 69.48 & 11.54 & 54.37 & 81.10 \\
Monthly Wages per Employee in Industry (Euro) & 1981.83 & 344.76 & 1238.0 & 4384.32 \\
Prop. of employees in farming & 4.32 & 2.69 & 0.22 & 13.82 \\
Prop. of employees in manufacturing & 31.88 & 7.32 & 12.75 & 46.13 \\
Prop. of highly skilled employees (university or poly- & 8.83 & 3.07 & 4.00 & 22.5 \\
technic degree) & & & & \\
Average number of employees per establishment in & 81.77 & 25.38 & 42.74 & 215.86 \\
manufacturing & & & & \\
Population density & 327.95 & 428.68 & 40.86 & 2459.76 \\
Votes for liberal-conservative parties (CDU plus FDP) & 43.26 & 10.25 & 14.8 & 66.6 \\
\hline \hline
\end{tabular}

Notes: Non-weighted sample statistic for all specifications in Table 5. ${ }^{*}$ relative to total labour force.

Table A4: Instrumenting ALMP - First-Differenced (SUR) Estimation

\begin{tabular}{|c|c|c|c|c|c|c|}
\hline & \multicolumn{2}{|c|}{ jcs } & \multicolumn{2}{|c|}{ sas } & \multicolumn{2}{|c|}{$p t$} \\
\hline & Coef. & $t$-value & Coef. & $t$-value & Coef. & $t$-value \\
\hline Unemployment rate $(t-2)$ & 2.064 & 9.18 & 0.041 & 0.26 & 0.097 & 0.91 \\
\hline Prop. of young in labour force $(t-1)$ & 9.375 & 1.51 & 1.142 & 0.24 & 0.850 & 0.3 \\
\hline Prop. of young in labour force $(t-2)$ & -10.252 & -1.89 & -9.171 & -2.16 & 3.537 & 1.37 \\
\hline Prop. of older unemployed $(t-1)$ & -1.561 & -1.26 & -1.593 & -1.78 & -0.870 & -1.49 \\
\hline Prop. of older unemployed $(t-2)$ & 5.733 & 4.72 & -1.892 & -2.12 & 1.028 & 1.77 \\
\hline Prop. of foreign unemployed $(t-1)$ & 12.123 & 1.52 & & & 7.760 & 2.04 \\
\hline Prop. of foreign unemployed $(t-2)$ & 18.696 & 2.26 & & & 3.430 & 0.87 \\
\hline Prop. of female unemployed $(t-1)$ & -2.604 & -3.29 & -0.766 & -1.33 & 0.100 & 0.27 \\
\hline Prop. of female unemployed $(t-2)$ & -2.607 & -3.29 & -0.387 & -0.64 & 0.361 & 0.94 \\
\hline Prop. of unemployed with UB $(t-1)$ & 0.068 & 0.11 & 1.048 & 2.42 & -0.069 & -0.24 \\
\hline Prop. of unemployed with UB (t-2) & -0.959 & -1.56 & 0.277 & 0.62 & -1.189 & -4.05 \\
\hline Aggregate Unemployment Rate $(t-1)$ & -1.629 & -2.08 & 2.722 & 4.47 & -0.463 & -1.21 \\
\hline Aggregate Unemployment Rate $(t-2)$ & -2.012 & -2.66 & 0.277 & 0.41 & -0.869 & -2.33 \\
\hline Aggregate Vacancy Rate $(t-1)$ & 0.583 & 1.44 & -0.652 & -2.05 & 0.010 & 0.05 \\
\hline Aggregate Vacancy Rate $(t-2)$ & -0.810 & -1.96 & -0.541 & -1.42 & -0.362 & -1.74 \\
\hline Prop. of welfare recipients in the pop. $(t-1)$ & -0.007 & -1.83 & -0.003 & -1.28 & -0.003 & -1.59 \\
\hline Votes for liberal-conservative parties $(t-1)$ & -0.029 & -1.35 & 0.022 & 1.42 & 0.003 & 0.25 \\
\hline Votes for liberal-conservative parties $x$ trend $(t-1)$ & -0.001 & -1.13 & -0.002 & -6.2 & -0.001 & -5.12 \\
\hline Welfare recip. $x$ liberal-conservative $x$ trend $(t-1)$ & 0.000 & 2.03 & 0.000 & 1.65 & 0.000 & 1.54 \\
\hline linear trend & -0.100 & -2.38 & & & & \\
\hline Quarter 2 & -0.049 & -0.32 & 0.212 & 1.88 & 0.123 & 1.69 \\
\hline Quarter 3 & -0.119 & -0.97 & 0.497 & 4.60 & 0.136 & 2.22 \\
\hline Quarter 4 & 0.031 & 0.32 & 0.589 & 7.42 & -0.023 & -0.48 \\
\hline Prop. of foreigner in labour force $(t-1)$ & & & -9.108 & -0.55 & 15.21 & 1.4 \\
\hline Prop. of foreigner in labour force $(t-2)$ & & & -28.98 & -1.49 & 12.33 & 0.97 \\
\hline Prop. of women in labour force $(t-1)$ & & & 9.365 & 1.84 & & \\
\hline Prop. of women in labour force $(t-1)$ & & & -4.651 & -1.06 & & \\
\hline Breusch-Pagan test of independence ( $p$-value) & \multicolumn{6}{|c|}{$\chi 2(3)=13.668(0.0034)$} \\
\hline Correlation matrix of residuals & \multicolumn{2}{|c|}{ jcs } & \multicolumn{2}{|c|}{ sas } & \multicolumn{2}{|c|}{$p t$} \\
\hline jcs & \multicolumn{2}{|c|}{1.0000} & & \\
\hline sas & \multirow{2}{*}{\multicolumn{2}{|c|}{$\begin{array}{l}0.1138 \\
0.1396\end{array}$}} & & & \multirow{2}{*}{\multicolumn{2}{|c|}{1.000}} \\
\hline$p t$ & & & \multicolumn{2}{|c|}{-0.010} & & \\
\hline No. & \multirow{2}{*}{\multicolumn{2}{|c|}{$\begin{array}{r}35,8 \\
04875\end{array}$}} & \multirow{2}{*}{\multicolumn{2}{|c|}{$\begin{array}{c}35,8 \\
0.6096\end{array}$}} & \multirow{2}{*}{\multicolumn{2}{|c|}{$\begin{array}{c}35,8 \\
0.2369\end{array}$}} \\
\hline & & & & & & \\
\hline
\end{tabular}

Notes: First-stage estimation for column (5) in Table 2. 
Table A5: Unit Root Tests for Monthly Panel Data

\begin{tabular}{|c|c|c|c|c|c|c|c|c|c|c|}
\hline \multirow[t]{2}{*}{ lags } & \multicolumn{2}{|c|}{$j s r_{i t}$} & \multicolumn{2}{|l|}{$\boldsymbol{V}_{i t}$} & \multicolumn{2}{|c|}{$j c s_{i t}$} & \multicolumn{2}{|c|}{$\operatorname{sas}_{i t}$} & \multicolumn{2}{|c|}{$p t_{i t}$} \\
\hline & ADF & $\mathrm{C}_{0.05}$ & ADF & $\mathrm{C}_{0.05}$ & ADF & $\mathrm{C}_{0.05}$ & ADF & $\mathrm{C}_{0.05}$ & ADF & $\mathrm{C}_{0.05}$ \\
\hline 1 & 425.330 & 21.412 & 465.282 & 21.412 & 675.743 & 21.412 & 453.369 & 21.412 & 631.186 & 21.412 \\
\hline 2 & 933.429 & 21.578 & 622.853 & 21.578 & 431.659 & 21.578 & 208.022 & 21.578 & 1248.525 & 21.578 \\
\hline 3 & 596.918 & 21.751 & 964.947 & 21.751 & 537.655 & 21.751 & 234.070 & 21.751 & 613.626 & 21.751 \\
\hline 4 & 466.528 & 21.931 & 729.837 & 21.931 & 435.921 & 21.931 & 351.964 & 21.931 & 530.415 & 21.931 \\
\hline 5 & 416.538 & 22.120 & 568.135 & 22.120 & 396.766 & 22.120 & 591.281 & 22.120 & 627.145 & 22.120 \\
\hline 6 & 512.167 & 22.318 & 581.823 & 22.318 & 371.777 & 22.318 & 540.462 & 22.318 & 654.134 & 22.318 \\
\hline 7 & 449.439 & 22.525 & 681.206 & 22.525 & 289.996 & 22.525 & 347.501 & 22.525 & 550.566 & 22.525 \\
\hline 8 & 270.361 & 22.744 & 634.840 & 22.744 & 303.708 & 22.744 & 206.179 & 22.744 & 600.964 & 22.744 \\
\hline 9 & 357.845 & 22.974 & 446.763 & 22.974 & 300.550 & 22.974 & 267.606 & 22.974 & 461.321 & 22.974 \\
\hline 10 & 564.350 & 23.218 & 432.073 & 23.218 & 315.358 & 23.218 & 263.841 & 23.218 & 350.229 & 23.218 \\
\hline 11 & 964.569 & 23.476 & 289.150 & 23.476 & 462.232 & 23.476 & 291.737 & 23.476 & 307.581 & 23.476 \\
\hline 12 & 741.916 & 23.751 & 424.444 & 23.751 & 382.194 & 23.751 & 400.750 & 23.751 & 429.615 & 23.751 \\
\hline
\end{tabular}

Notes: ADF is the test statistic of the augmented Dickey Fuller Test for panel data as proposed by SARNO and TAYLOR (1998) and TAYLOR and SARNO (1998). C $_{0.05}$ is the 5 per cent critical value, the null hypothesis of a unit root is rejected if $A D F<C_{0.05}$.

Table A6: Estimation Results - Augmented Beveridge Curve

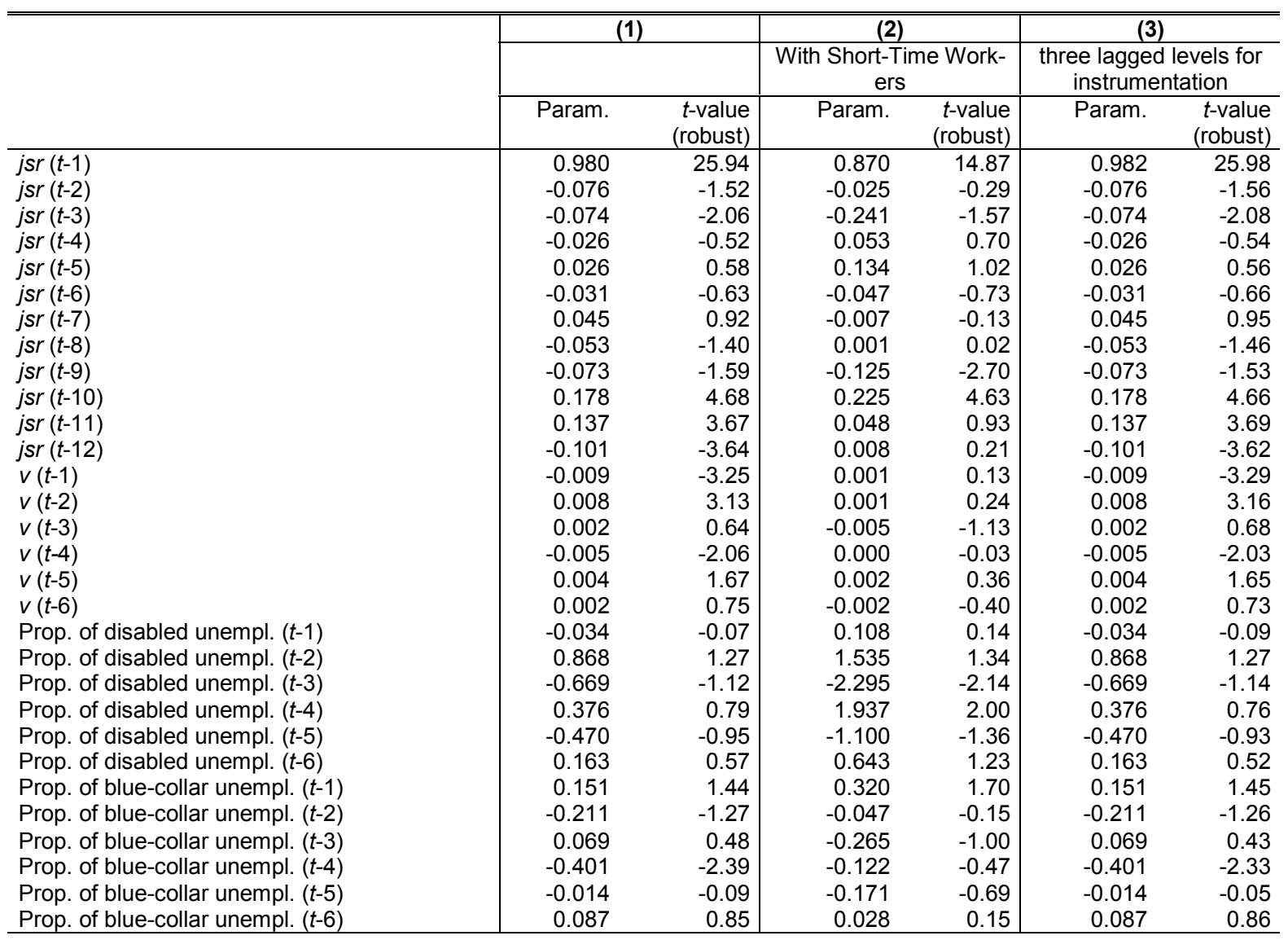


Table A6 - continued

\begin{tabular}{|c|c|c|c|c|c|c|}
\hline Prop. of young in labour force $(t-1)$ & -0.611 & -2.35 & -0.730 & -2.08 & -0.611 & -2.38 \\
\hline Prop. of young in labour force $(t-2)$ & 0.570 & 1.97 & 0.489 & 1.22 & 0.570 & 1.95 \\
\hline Prop. of young in labour force $(t-3)$ & -0.414 & -1.26 & -0.310 & -0.72 & -0.414 & -1.25 \\
\hline Prop. of young in labour force $(t-4)$ & -0.262 & -0.77 & -0.429 & -0.76 & -0.262 & -0.73 \\
\hline Prop. of young in labour force $(t-5)$ & -0.133 & -0.34 & -0.178 & -0.33 & -0.133 & -0.33 \\
\hline Prop. of young in labour force $(t-6)$ & 0.594 & 2.27 & 0.810 & 2.79 & 0.594 & 2.24 \\
\hline Prop. of female unempl. $(t-1)$ & -0.154 & -1.72 & -0.139 & -1.02 & -0.154 & -1.71 \\
\hline Prop. of female unempl. ( $t-2)$ & 0.063 & 0.43 & 0.275 & 0.93 & 0.063 & 0.47 \\
\hline Prop. of female unempl. $(t-3)$ & 0.218 & 1.61 & -0.122 & -0.28 & 0.218 & 1.64 \\
\hline Prop. of female unempl. $(t-4)$ & -0.282 & -1.70 & -0.227 & -0.62 & -0.282 & -1.73 \\
\hline Prop. of female unempl. ( $t-5)$ & -0.351 & -2.79 & -0.247 & -1.00 & -0.351 & -2.72 \\
\hline Prop. of female unempl. $(t-6)$ & 0.316 & 3.04 & 0.347 & 2.70 & 0.316 & 3.07 \\
\hline Prop. of foreign unempl. $(t-1)$ & 0.407 & 1.01 & 0.930 & 1.49 & 0.423 & 1.04 \\
\hline Prop. of foreign unempl. (t-2) & 0.106 & 0.19 & 0.033 & 0.04 & 0.106 & 0.16 \\
\hline Prop. of foreign unempl. $(t-3)$ & -0.177 & -0.29 & -0.116 & -1.29 & -0.177 & -0.31 \\
\hline Prop. of foreign unempl. $(t-4)$ & 0.163 & 0.29 & 0.104 & 0.97 & 0.163 & 0.11 \\
\hline Prop. of foreign unempl. $(t-5)$ & 0.156 & 0.25 & 0.308 & 0.34 & 0.156 & 0.25 \\
\hline Prop. of foreign unempl. ( $t-6)$ & 0.074 & 0.16 & -0.928 & -1.27 & 0.074 & 0.14 \\
\hline $\operatorname{acccr} j c s(t)$ & -0.001 & -0.27 & -0.009 & -1.18 & -0.001 & -0.22 \\
\hline $\operatorname{acccr} j c s(t-1)$ & 0.000 & 0.02 & 0.012 & 1.01 & 0.000 & 0.01 \\
\hline $\operatorname{acccr} j c s(t-2)$ & 0.007 & 1.24 & 0.012 & 1.07 & 0.007 & 1.25 \\
\hline $\operatorname{acccr} j c s(t-3)$ & -0.009 & -1.81 & -0.033 & -1.73 & -0.009 & -1.83 \\
\hline $\operatorname{acccr} j c s(t-4)$ & 0.004 & 0.80 & 0.032 & 1.44 & 0.004 & 0.76 \\
\hline $\operatorname{acccr} j c s(t-5)$ & -0.004 & -0.81 & -0.018 & -1.47 & -0.004 & -0.82 \\
\hline $\operatorname{acccr} j c s(t-6)$ & 0.003 & 0.43 & 0.012 & 0.97 & 0.003 & 0.42 \\
\hline $\operatorname{acccr} j c s(t-7)$ & 0.004 & 0.86 & -0.007 & -0.78 & 0.004 & 0.84 \\
\hline $\operatorname{acccr} j c s(t-8)$ & -0.006 & -1.53 & -0.017 & -2 & -0.006 & -1.52 \\
\hline $\operatorname{acccr} j c s(t-9)$ & 0.002 & 0.41 & 0.014 & 2.27 & 0.002 & 0.42 \\
\hline $\operatorname{acccr} j c s(t-10)$ & 0.005 & 0.89 & -0.003 & -0.5 & 0.005 & 0.96 \\
\hline $\operatorname{acccr} j c s(t-11)$ & -0.004 & -0.71 & 0.007 & 1.07 & -0.004 & -0.72 \\
\hline $\operatorname{acccr} j c s(t-12)$ & -0.003 & -0.82 & -0.006 & -1.35 & -0.003 & -0.84 \\
\hline $\operatorname{acccr} \operatorname{sas}(t)$ & -0.001 & -0.21 & 0.026 & 1.83 & -0.001 & -0.25 \\
\hline acccr sas $(t-1)$ & -0.006 & -1.07 & -0.055 & -2.68 & -0.006 & -1.02 \\
\hline acccr sas $(t-2)$ & 0.002 & 0.72 & 0.012 & 1.35 & 0.002 & 0.78 \\
\hline acccr sas $(t-3)$ & -0.004 & -0.92 & 0.000 & -0.04 & -0.004 & -0.95 \\
\hline acccr sas (t-4) & -0.005 & -1.11 & 0.015 & 0.85 & -0.005 & -1.16 \\
\hline acccr sas $(t-5)$ & 0.011 & 2.89 & -0.011 & -0.62 & 0.011 & 2.88 \\
\hline acccr sas $(t-6)$ & -0.002 & -0.35 & -0.003 & -0.37 & -0.002 & -0.31 \\
\hline acccr sas (t-7) & -0.001 & -0.1 & 0.006 & 0.64 & -0.001 & -0.15 \\
\hline acccr sas $(t-8)$ & 0.009 & 2.21 & 0.020 & 1.79 & 0.009 & 2.23 \\
\hline acccr sas $(t-9)$ & -0.002 & -0.45 & -0.013 & -1.47 & -0.002 & -0.46 \\
\hline acccr sas $(t-10)$ & -0.007 & -1.65 & -0.002 & -0.29 & -0.007 & -1.64 \\
\hline acccr sas $(t-11)$ & -0.007 & -0.99 & -0.005 & -0.54 & -0.007 & -0.97 \\
\hline acccr sas $(t-12)$ & 0.010 & 2.07 & 0.002 & 0.27 & 0.010 & 2.05 \\
\hline $\operatorname{acccr} p t(t)$ & -0.047 & -5.44 & -0.045 & -4.89 & -0.047 & -5.40 \\
\hline $\operatorname{acccr} p t(t-1)$ & 0.059 & 5.16 & 0.044 & 3.23 & 0.059 & 5.11 \\
\hline $\operatorname{acccr} p t(t-2)$ & -0.011 & -1.28 & -0.003 & -0.25 & -0.011 & -1.23 \\
\hline acccr pt $(t-3)$ & -0.001 & -0.21 & -0.016 & -1.73 & -0.001 & -0.22 \\
\hline $\operatorname{acccr} p t(t-4)$ & -0.010 & -0.97 & 0.012 & 1.01 & -0.010 & -0.95 \\
\hline acccr pt $(t-5)$ & 0.015 & 1.79 & 0.002 & 0.16 & 0.015 & 1.74 \\
\hline $\operatorname{acccr} p t(t-6)$ & -0.016 & -2.00 & 0.011 & 0.74 & -0.016 & -2.02 \\
\hline acccr pt $(t-7)$ & -0.003 & -0.29 & -0.038 & -2.17 & -0.003 & -0.24 \\
\hline acccr pt $(t-8)$ & 0.019 & 2.36 & 0.046 & 2.75 & 0.019 & 2.33 \\
\hline $\operatorname{acccr} p t(t-9)$ & -0.018 & -2.19 & -0.035 & -1.98 & -0.018 & -2.24 \\
\hline acccr pt $(t-10)$ & 0.016 & 1.77 & 0.019 & 0.97 & 0.016 & 1.78 \\
\hline acccr pt $(t-11)$ & -0.007 & -0.88 & -0.012 & -0.76 & -0.007 & -0.85 \\
\hline acccr pt $(t-12)$ & 0.004 & 0.94 & 0.006 & 0.86 & 0.004 & 0.96 \\
\hline In national unemployment rate $(t-1)$ & 0.397 & 8.38 & 0.429 & 7.09 & 0.397 & 8.35 \\
\hline In national unemployment rate $(t-2)$ & -0.271 & -3.35 & -0.367 & -3.88 & -0.271 & -3.33 \\
\hline In national unemployment rate $(t-3)$ & -0.030 & -0.31 & 0.128 & 0.89 & -0.035 & -0.32 \\
\hline In national unemployment rate $(t-4)$ & -0.012 & -0.14 & 0.064 & 0.45 & -0.012 & -0.15 \\
\hline In national unemployment rate $(t-5)$ & -0.228 & -2.56 & -0.187 & -1.55 & -0.228 & -2.51 \\
\hline In national unemployment rate $(t-6)$ & 0.153 & 1.67 & 0.011 & 0.10 & 0.153 & 1.66 \\
\hline In national vacancy rate $(t-1)$ & -0.015 & -0.17 & -0.121 & -1.08 & -0.015 & -0.15 \\
\hline In national vacancy rate $(t-2)$ & -0.046 & -0.38 & 0.145 & 0.85 & -0.046 & -0.33 \\
\hline In national vacancy rate $(t-3)$ & 0.225 & 3.32 & 0.121 & 1.09 & 0.225 & 3.31 \\
\hline In national vacancy rate $(t-4)$ & -0.360 & -2.93 & -0.313 & -2.32 & -0.360 & -2.94 \\
\hline In national vacancy rate $(t-5)$ & 0.166 & 1.22 & 0.143 & 0.99 & 0.166 & 1.21 \\
\hline In national vacancy rate $(t-6)$ & 0.016 & 0.19 & 0.027 & 0.24 & 0.014 & 0.80 \\
\hline Constant & 0.000 & -0.37 & 0.000 & 0.14 & 0.000 & -0.35 \\
\hline Sargan test $\chi 2$ (p-value) & \multirow{4}{*}{\multicolumn{2}{|c|}{$\begin{array}{c}1180.80 \quad(1.0000) \\
0.0000 \\
0.3403 \\
35,37\end{array}$}} & \multicolumn{2}{|c|}{$1199.72(1.0000)$} & \multicolumn{2}{|c|}{$1180.80(1.0000)$} \\
\hline 1st order serial correlation, $p$-value & & & 0.00 & & 0.00 & \\
\hline 2st order serial correlation, $p$-value & & & 0.74 & & $0.3<$ & \\
\hline No. of observations $(N, T)$ & & & 35 & & 35 & \\
\hline
\end{tabular}

Notes: 11 monthly dummies are included but not reported. 